\title{
Prof. Dr. Bedi N. Şehsuvaroğlu, Türk Tıp Tarihi ve Kültürüne Katkıları*
}

\section{The Contributions of Prof. Dr. Bedi N. Şehsuvaroğlu to Turkish Medical History and Cultural Studies}

\author{
Nuran Y1ldırım ${ }^{1}$ (1)
}

*Sözlü bildiri olarak sunulmuş olup sadece özeti yayınlanmışıtır. Nuran Yıldıım, "Vefatının 40. Yilında Prof. Dr. Bedi N. Şehsuvaroğlu'nun Türk Tip Tarihi ve Kültürüne Katkıları," Sivas Dârüşşifası́nın 800. Yilı Anısına XIII. Türk Tip Tarihi Kongresi, Sivas, 18-21 Ekim 2017, Program ve Bildiri Özetleri içinde [Sivas: Türk Tip Tarihi Kurumu, 2017], 85.

'Prof. Dr., Bezmialem Vakıf Üniversitesi, Tip Fakültesi, Tip Tarihi ve Etik Anabilim Dalı, Istanbul, Türkiye

\section{ORCID: N.Y. 0000-0002-3537-3814}

\section{Sorumlu yazar/Corresponding author:} Nuran Yıldırım,

Bezmialem Vakıf Üniversitesi, Tıp Fakültesi, Tip Tarihi ve Etik Anabilim Dal,, İstanbul, Türkiye E-posta/E-mail: nurany@gmail.com

Başvuru/Submitted: 26.06 .2019 Revizyon Talebi/Revision Requested: 08.08.2019

Son Revizyon/Last Revision Received: 26.10.2019

Kabul/Accepted: 04.11.2019

Online Yayın/Published Online: 03.01 .2020

\section{Atıf/Citation:}

Yıldırım, Nuran. "Prof. Dr. Bedi N. Şehsuvaroğlu, TürkTip Tarihi ve Kültürüne Katkıları." Osman/ı Bilimi Araştırmaları 21, 1 (2020): 151-192. https://doi.org/10.26650/oba.582396

\section{öz}

Prof. Dr. med.et phil. Bedi N. Şehsuvaroğlu, İstanbul Üniversitesi Tıp Fakültesi Tıp Tarihi ve Deontoloji Kürsüsü’nde çalıştığı 1950-1977 yılları arasında başta tıp tarihi ve tıbbi deontoloji olmak üzere, eczacılık ve diş hekimliği tarihi alanlarında orijinal kaynaklara dayalı nitelikli yayınlar yapmıştır. 1933'te Tıp Tarihi Enstitüsü içinde kurulan, Türkiye'nin ilk Tıp Tarihi Müzesini özel çabalarıyla geliştirmiş, ilk Osmanlı darphanesi Simkeşhâne'nin restorasyonunu sağlamıştır. İstanbul'un köprüleri, anıtları, çeşmeleri, dikilitaşları, müzeleri, sarayları, surları, şiddetli kışları, yangınları ve benzer konularda yazdığı makalelerle şehrin tarihine ve kültürüne sahip çıkmıştır Göztepe kitabıyla semt tarihçiliğini başlatmıştır. Bu makale, Bedi N. Şehsuvaroğlu'nun tıp tarihi ve tıbbi deontoloji yanında tarih ve kültür alanlarına ve sağlık müzeciliğine önemli katkılar yapmış olan yayınlarını tanıtmayı amaçlamaktadır.

Anahtar sözcükler: TürkTıp Tarihi, tıbbi deontoloji, tıp tarihi müzesi, Göztepe, Simkeşhâne

\section{ABSTRACT}

Professor Dr. med. et phil. Bedi N. Şehsuvaroğlu was a member of the Department of the History of Medicine and Deontology, at Istanbul University Faculty of Medicine between 1950 and 1977. He is known for a series of widely acclaimed articles in the history of medicine, medical deontology, the history of dentistry and pharmacology. He contributed greatly to the establishment of the first Museum of Medical History in Turkey, and to the restoration of the first Ottoman mint, Simkeşhâne. Through his articles on the bridges, monuments, fountains, obelisks, museums, palaces, city walls, climate and fires of Istanbul, he kept the history of the city alive. He wrote monographs about Istanbul's districts such as Göztepe. The present article aims to review the contribution of Prof. Dr. Bedi Şehsuvaroğlu to the above mentioned fields by focusing on his publications in those areas.

Keywords: Turkish history of medicine, medical deontology, museum of medical history 


\section{Giriş}

Türk Tıp Tarihi’nin öncüleri sayılan Galip Ata Ataç (1880-1947), Osman Şevki Uludağ (1889-1964), A. Süheyl Ünver (1898-1986), Feridun Nâfiz Uzluk (1902-1974) ve Bedi N. Şehsuvaroğlu (1914-1977), tıp tarihi yanında tarihe, sanata, kültüre ve ulusal değerlere önem veren çok yönlü bilim insanlarıydı. Şehsuvaroğlu, diğerlerinden daha genç olmakla birlikte onlar kadar ömür süremedi. En verimli çağında bu dünyaya veda etti. Bu makalede, 1970-1977 yıllarında kendisiyle yedi sene çalışmış bir öğrencisi olarak hocamın ailesi, eğitimi, yaşamı ve akademik hayatına değindikten sonra çalışmalarını, eğitim-öğretim faaliyetlerini, bilimsel araştırma ve yayınlarını, düzenlediği kongreleri, tıp tarihi müzeciliğini, arşivini, yetişmesine katkıda bulunduğu öğrencilerini ve kültürel faaliyetlerini değerlendirmeye çalışacağım. Ayrıca, son dört yılını anabilim dalı başkanı olarak geçirdiğim 1970-2015 yıllarını kapsayan 45 yıllık dönemde, Prof. Dr. Bedi N. Şehsuvaroğlu'nun İstanbul Üniversitesi İstanbul Tıp Fakültesi Tıp Tarihi ve Etik Anabilim Dalı'na bıraktığı mirasın durumuna da değineceğim.

\section{Ailesi}

Bedi N. Şehsuvaroğlu'nun babası, Mekteb-i T1bbiye-i Şâhâne'nin 1901 (1317) mezunlarından Bahriye Korvet Tabibi Binbaşı Yusuf Selâmi Bey’dir (d.1880). ${ }^{1}$ Üsküdar Bidâyet Mahkemesi Reisi Neş'et Bey'in oğlu olan Dr. Yusuf Selami Neş'et, babaannesi yoluyla Dulkadiroğulları'nın Şehsuvar Bey koluna, anneannesi tarafından da Topuzluoğulları'na mensuptur. Annesi Şefika Nurinnisa Hanım, eski tümen komutanlarından Miralay Arif Bey’in kızıdır. $^{2}$

Yusuf Selami Bey, Üsküdarlı Mehmet Neş’et Bey’in oğludur. Eskiden soyadı yerine baba adı kullanıldığından daha çok Selami Neş'et adını kullanmıştır. Deniz Arşivi Âmiri M. Adnan Yalın tarafından, arşiv kayıtlarına uygun olarak hazırlanan 30 Mayıs 1967 tarihli belgeye göre, Yusuf Selami 13 Şubat 1898'de Harbiye'ye girmiş3 (sicil no. Dz. 29), 27 Şubat 1902'de Tabib Yüzbaşı, 23 Temmuz 1908'de Solkolağası, 19 Temmuz 1915'te Korvet Tabibi Binbaşı olmuştur. 31 Ekim 1915 tarihinde emekli olduktan sonra Ankara'da belediye tabipliği yaparken vefat etmiştir (20 Şubat 1331/4 Mart 1916). Gümüş Liyakat Madalyası sahibiydi. ${ }^{4}$

Şehsuvaroğlu'na ait en eski belge, 30 Mayıs 1330 (12 Haziran 1914) tarihli Devlet-i Aliyye-i Osmaniye [Çiçek] Aşı Tasdiknâmesi'dir. Burada adı İsmail Bedi Nuri

1 Riza Tahsin, Mir'ât-ı Mekteb-i Trbbiye. Íkinci Kitap ([Dersaadet]: [Kader Matbaas1], 1328 [1912]), 170.

2 Bedi N. Şehsuvaroğlu'nun biyografisi arkadaşı Gen. Dr. Nazmi Çağan tarafından yazılmış olup Şehsuvaroğlu'nun kontrolünden geçmiştir. Nazmi Çağan, Bedi N. Şehsuvaroğlu Biyografi ve Bibliyografyası II (1947-1970) (İstanbul: İstanbul Şehir Kütüphanesi Koruma ve Yaşatma Derneği, 1973), 7-10, 25-27. Bu yayında babasının ölüm tarihi yanlıştır. Bu yanlış, 20 Şubat 1331 tarihinde sadece 1331 yılının 1915 olarak çevrilmesinden kaynaklanmaktadır. Oysa bu tarihin Miladi takvimdeki karşlığı 4 Mart 1916'dır.

3 "Harbiye'ye girmiş" ifadesiyle Harbiye Nezareti'ne girişi kastedilmektedir.

4 Rıza Tahsin, Mir'ât-ı Mekteb-i Tıbbiye, 170. 
olarak geçmektedir. ${ }^{5} \mathrm{O}$ tarihte iki buçuk aylıktır, çiçek aşısını yapan tabip olarak babasının mührü bulunmaktadır. Doğum tarihi 10 Mart 1330 (23 Mart 1914), doğum yeri BeyazıtEmin Bey Mahallesi, Enfiyeci Sokak, mükerrer 8 nolu hane olarak kaydedilmiştir. İstanbul Tıp Fakültesi öğrenci arşivindeki dosyasında ve Selami A. Şehsuvaroğlu’nda bulunan nüfus cüzdanı suretlerinde de doğum tarihi, Hicri ve Rûmi takvimlere göre 26 Rebiülâhır 1332 / 10 Mart 1330 şeklinde yazılmıştır. ${ }^{6}$
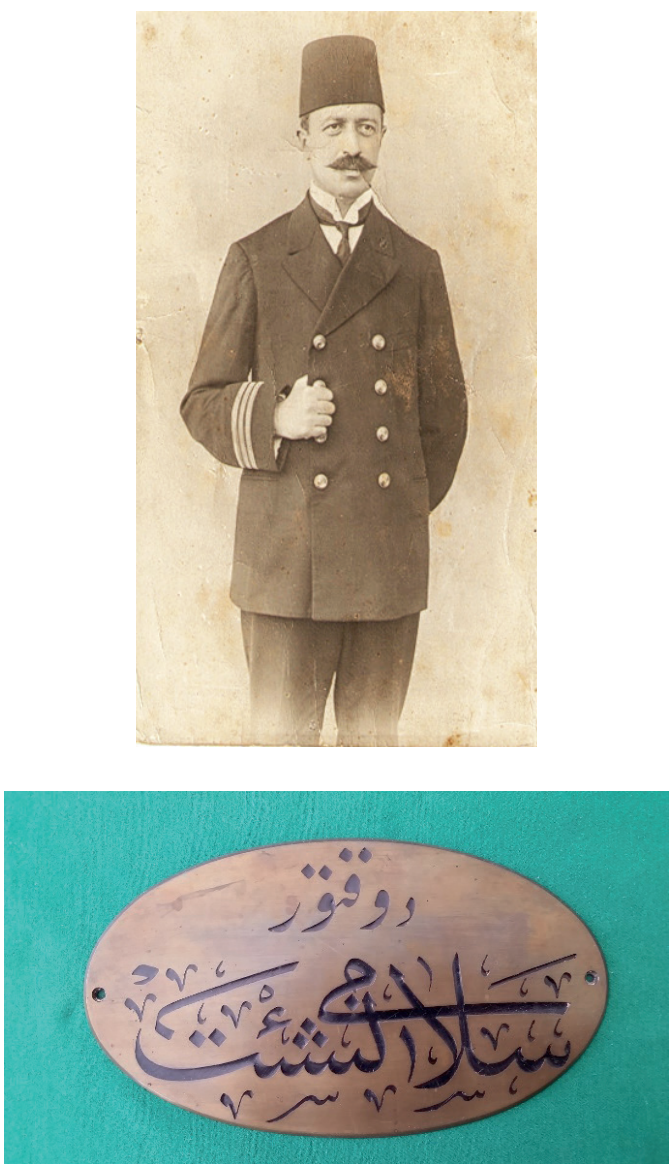

Bedi N. Şehsuvaroğlu'nun babası Dr. Kolağası Yusuf Selami Neş’et Bey ve tabelası (Selami Ahmet Şehsuvaroğlu Arşivi).

5 Adı, bu belgede Arap harfleriyle Bedî’ olarak yazılmış olup "emsali olmayan, yeni, görülmemiş, benzersiz, nadide” anlamına gelir. Bkz. Şemseddin Sami, Kamus-ı Türkî (Dersaadet: İkdam Matbaası, 1317). Öğrencilik ve özlük dosyalarındaki bütün belgelerde ve yazışmalarda adı "Bedi” olarak geçmektedir. "Bedii" yazılışı doğru değildir.

6 İstanbul Üniversitesi İstanbul Tıp Fakültesi Dekanlığındaki özlük dosyasında bulunan kendi yazmış olduğu biyografisinde doğum tarihini 23 Mart 1330 (1914) olarak vermiştir. Fakat Şehsuvaroğlu'na ait en eski belge olan çiçek aşısı tasdiknamesi ile İstanbul Tıp Fakültesi öğrenci dosyasında bulunan nüfus cüzdanı suretinde doğum tarihi 10 Mart 1330 [23 Mart 1914] olarak kayıtlıdır. Biz bu iki belgeyi esas aldık. 

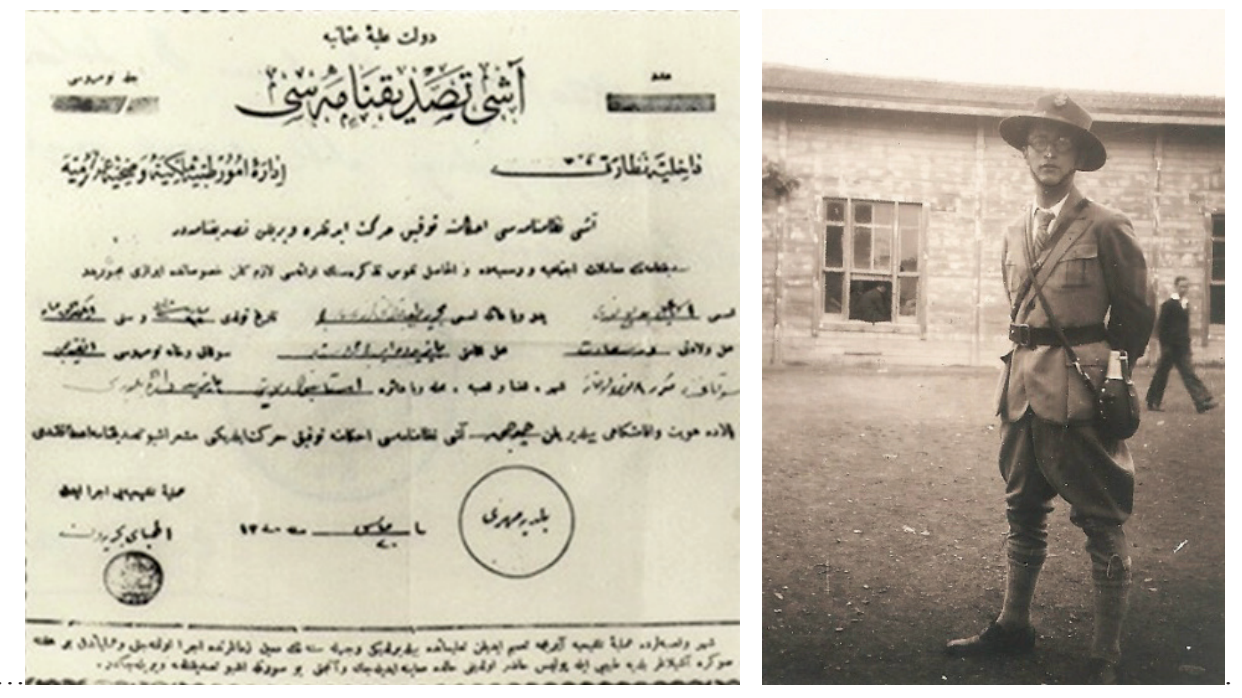

Bedi N. Şehsuvaroğlu'nun çiçek aşısı tasdiknamesi (12 Haziran 1914) ve Kadıköy Lisesi izcisiyken Ankara gezisinde çekilmiş bir fotoğrafı (26 Ekim 1932) (Selami Ahmet Şehsuvaroğlu Arşivi).

Babası Selâmi Neş’et Bey’in vefatından sonra annesi Şefika Nurünnisa Hanım küçük oğlu İsmail Bedi Nuri ile iki kızını tek başına büyütmek zorunda kalmıştır. Kızlarından Leman Hanım ev kadını olmuş, Hayrünnisa Hanım uzun yıllar İstanbul'da Türkçe ve Edebiyat öğretmeni olarak çalışmıştır.

4 Nisan 1952 tarihli nüfus cüzdanı suretinde; 2 Mayıs 1936'da "Şehsuvaroğlu” soyadını aldığı kayıtlıdır. ${ }^{7}$ Bundan sonra "İsmail” ön adını terk edip, Bedi Nuri Şehsuvaroğlu adını kullanmıştır. Bu nüfus cüzdanı suretine göre; ilk evliliğini Mustafa İhya kızı Ayşe Aliye ile yapmış (22 Mart 1946) fakat ertesi sene boşanmıştır (9 Nisan 1947). İstanbul Üniversitesi’nde çalışmaya başladıktan sonra, İstanbul Evkaf Vekili Avukat Abdullah Pirigil (İstanbul Barosu Sicil No. 238) ile Cumhuriyet'in ilk öğretmenlerinden Emine Aliye Esad Hanım'ın kızı Leyla Günseli ile evlenmiştir (29 Mart 1952). Kayınvalidesi Emine Aliye Esad Hanım (ö. 1985), Mir'ât-ı Mekteb-i Harbiye (İstanbul: 1310/1893) ve Mir'ât-ı Mühendishane-i Berrî-i Hümayun (İstanbul: 1312/1895) kitaplarının yazarı Mehmed Esad Bey'in (1849-1919) üç çocuğundan biriydi. İnas Darülfünunu Edebiyat Şubesi'nin ilk mezunlarındandı (2 Temmuz 1918). Vatansever kadınların kurduğu, Asrî Kadınlar Cemiyeti'nin (kuruluşu 1918) aktif üyelerindendi. İzmir'in işgalinden bir gün sonra, o günlerde en çok ihtiyaç duyulan birlik heyecanını ateşleyen bir bildiri yayınlayan (16 Mayıs 1919) Asrî Kadınlar Cemiyeti, İnas Darülfünunu ile birlikte İstanbul-Fatih'te düzenlediği büyük mitingde İzmir'in işgalini

72741 sayılı Soyadı Kanunu 21 Haziran 1934'te kabul edilmiş, 2 Temmuz 2934 tarihinde Resmi Gazete'de yayınlanarak yürürlüğe girmiştir. 
protesto etmişti (19 Mayıs 1919). Aliye Esad Hanım, kadınların siyasal haklarını kazanmaları için mücadele etmek amacını güden Türk Kadın Birliği'nin kurucuları arasındaydı (1923). 3 Nisan 1929 tarihli Belediyeler Kanunu ile kadınlara ilk siyasal hakların tanınmasını kutlamak için, Sultanahmet'te yapılan mitingde ateşli konuşması ile dikkati çekmişti (10 Nisan 1929). ${ }^{8}$ Türk Kadınlar Birliği’nin tüzel kişiliğini feshettiği fevkalâde kongrede, Genel Yazgan Aliye Esad Hanım hazırlamış olduğu raporu okumuştu (1935). ${ }^{9}$

Eşi Leyla Hanım, lirik sopranoydu, şairdi, ressamdı. Pek çok karma sergiye tablolarıyla katılmıştır. ${ }^{10}$ Gençliğinden itibaren yazmış olduğu şiirleri; Leyla Günseli Pirigil. Derlenmiş Şiirleri 1940-2010, adıyla yayınlandı. 1 Ocak 2017'de vefat eden Leyla Hanım, 4 Ocak 2017 'de eşinin yanına Karacaahmet Mezarlığına defnedilmiştir.

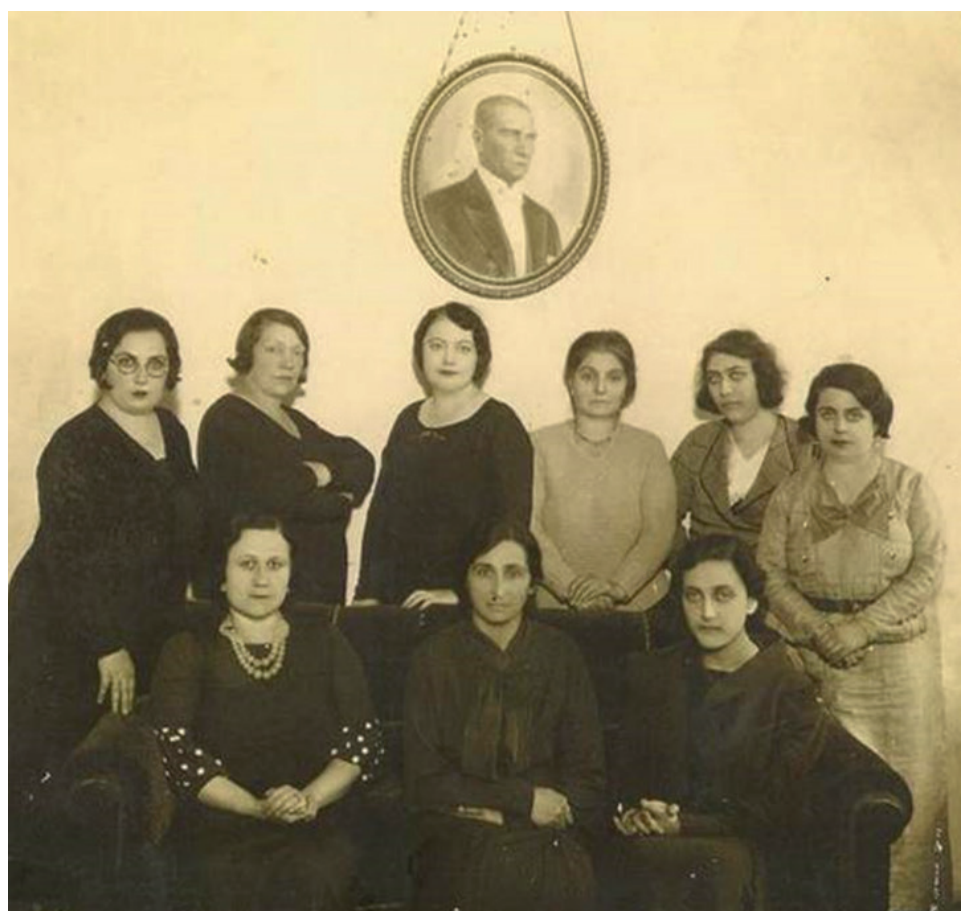

Kadın Birliği Heyet-i İdaresi. Arka sıraki soldan ikinci hanım, Bedi N. Şehsuvaroğlu'nun kayınvalidesi Aliye Esad Hanım’dır (Selami Ahmet Şehsuvaroğlu Arşivi).

8 Türk Kadın Birliği Kadın Sesi Cumhuriyetin 10uncu Ylldönümünü Kutlular, 1923 - 1933 (İstanbul: Ahmet İhsan Matbaası, 1933).

9 Yaprak Zihnioğlu, Kadınsız Inkılap, 1.bs (İstanbul: Metis, 2003), 152-153; Suphan Kirmizialtin, “Gender, Education, Modernization: Women School Teachers in the Late Ottoman Empire" (Doctoral dissertation, University of Texas, 2012), 244-248; Zafer Toprak, Türkiye'de Kadın Özgürlüğ̈̈ ve Feminizm (1908-1935) (İstanbul: Tarih Vakfi Yurt Yayınları, 2014), 467, 495, 497, 503.

10 “Ceramikcenter On'lar Gurubu Resim ve Heykel Sergisi (5-10 Mayıs 1990),” Milliyet, 6 May1s 1990. 


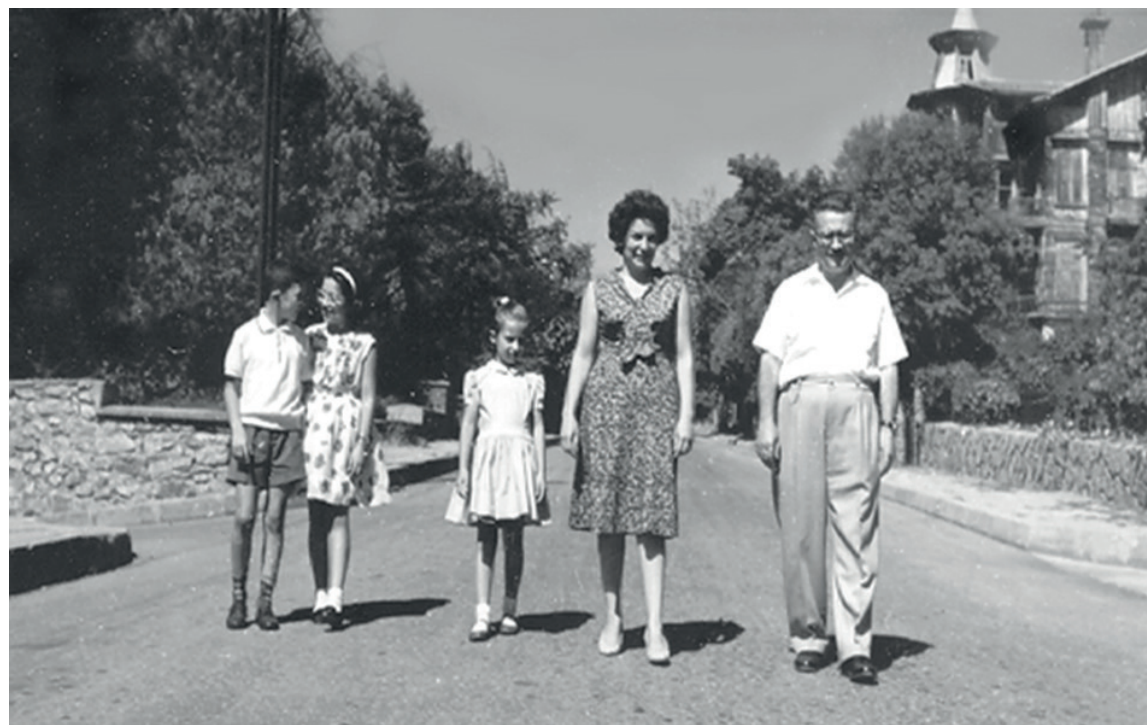

Bedi N. Şehsuvaroğlu ailesi. Göztepe Taşmektep Sokak, 1962 (Soldan sağa Selami, Lâle ve Nurdan Şehsuvaroğlu) (Selami Ahmet Şehsuvaroğlu Arşivi).

Bedi Bey üç çocuğundan iki kızına, Lâle Zeynep ve Hamide Nurdan isimlerini vermiştir. Kansas State University'de nükleer mühendislik eğitimi alan oğlu Selami Ahmet Şehsuvaroğlu, halen yeminli petrol mühendisi olarak uluslararası petrol ve doğalgaz danışmanlığı yapmakta olup Nice'de (Fransa) eşi Rose ile yaşamaktadır ve üç çocuk sahibidir: Séverine (Los Angeles), Douglas (Londra), Christopher (Cambridge). ${ }^{11}$ Selami Ahmet Şehsuvaroğlu, ön-üniversite eğitimini tamamladığı Cowley County Community College'de (Arkansas City, KS) babasının anısına, "Bedi N. Şehsuvaroğlu Bursu” ihdas etmiştir. 1970'lerde yazmaya başladığı şiirler önce Ankara'da Yeni Adam dergisinde, sonra da iki kitap halinde fotoğrafları ile beraber, İngilizce/Türkçe olarak yayınlanmıştır. Büyük kızı Lâle Zeynep, İstanbul Üniversitesi Edebiyat Fakültesi İngiliz Filolojisi’nde okumuş, daha sonra Seyhan Dirim ile evlenmiştir. Halen Brüksel'de eşi ve oğulları Burak ve Ali ile ikâmet etmektedir. İstanbul Üniversitesi Edebiyat Fakültesi Sanat Tarihi Bölümü mezunu olan diğer kızı, Hamide Nurdan, Prof. Ahmet Sarpyener ile evli olup eşiyle Brüksel'de yaşamakta, kızları Defne ise Kopenhag'da çalışmaktadır.

1990’larda nüfus kütükleri bilgisayara alınırken, bir klavye hatası yüzünden ailenin adı Şehsuvaroğlu yerine Şahsuvaroğlu olarak kayda geçirilmiştir. 1990'lar öncesi pasaportlar ve bütün resmi evrakta aile adı Şehsuvaroğlu'dur.

11 Selami Ali Şehsuvaroğlu günümüzde Al Şehsuvaroğlu ismini kullanmaktadır. Biyografisi için bkz. "Cowley alumnus now a respected international oil and gas consultant," 12 July 2016, erişim 27 Kasım 2018, https:// www.cowley.edu/news/releases/2015_16/071216_alumnus_gas_consultant.html 


\section{Eğitimi ve İlk Görevleri}

Orta öğrenimini Kabataş Lisesi’nde yapan İsmail Bedi Nuri, Kadıköy Lisesi’nden mezundur. Lisedeyken tarihe merakını fark eden tarih öğretmeni Mükrimin Halil Yinanç, tarihçi olmasını tavsiye eder. Fakat o, küçük yaşlarda baba mesleğini seçmişti, hekim olacaktı. İstanbul Üniversitesi Tıp Fakültesi'ne 1072 numara ile kaydoldu. Fakat önce Fen Fakültesi'nde P.C.N (sonraları FKB) eğitimi alması gerekiyordu. 1933-34 ders yılında Fen Fakültesi'nde kimya, nebatat (botanik), hayvanat (zooloji) ve fizik derslerine devam etti. Sene sonunda yazılı sınavlarda başarı göstermesi üzerine Haziran devresinde mezun olup P.C.N Tasdiknamesini aldı (no. 24, 21 Ağustos 1934). Ardından İstanbul Üniversitesi Rektörlüğü’ne verdiği 14 Ekim 1934 tarihli dilekçesiyle, parasız yatılı Leyli Tıp Talebe Yurdu'na' ${ }^{12}$ kaydolmak için gereken evrakı Sıhhiye ve İçtimai Muavenet Vekâleti'ne gönderdiğini bildirip Tıp Fakültesi'ne geçici kaydının yapılmasını istedi. O sırada Kadıköy'ün Mısırlığlu semtindeki "Çeşme Sokak, no.9" adresindeki evlerinde annesi ve ablasıyla birlikte oturmaktaydı. Her ne kadar evin bir katı kiradaysa da babası olmadığ 1 ve ablasının da bir geliri bulunmadığı için Leyli Tıp Talebe Yurdu'na kabul edildi.

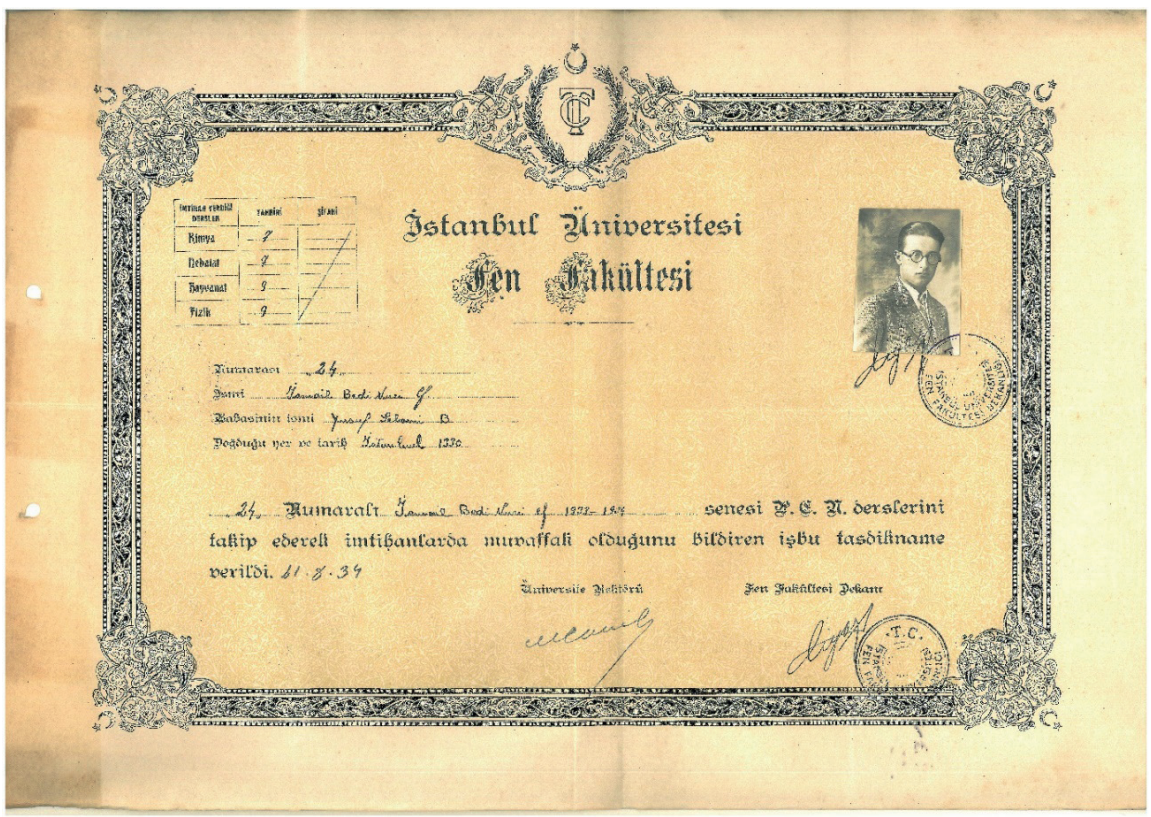

İsmail Bedi Nuri [Şehsuvaroğlu] Efendi’nin PCN (Kimya, Hayvanat, Nebatat, Fizik) tasdiknamesi, 21 Ağustos 1934

(İstanbul Üniversitesi İstanbul Tıp Fakültesi Öğrenci Arşivi, İsmail Bedi Nuri Ef., Şahsuvaroğlu dosyası).

12 Doğrudan Sıhhat ve İçtimai Muavenet Vekâleti’ne bağlı olan bu yurt, "1932 senesinden itibaren, Tıp Fakültesinden neş’et edecek tabiplerin mecburi hizmetlerinin lağvı ve leyli tıp talebe yurduna alınan tıp talebesinin tabi olacakları mecburiyetler hakkında kanun (Kanun no. 2000)" ile açılmıştır. Burada kalan öğrencilerin yiyecek-içecek, giyim, kitap ve okul masrafları karşılanırdı. Buna karşılık üç yıl mecburi hizmete tabi idiler. 
Leyli Tıp Talebe Yurdu'nda kalan öğrencilere Fransızca, Almanca ve İngilizce dersleri verilirdi. Öğrenciler eğitim süreleri boyunca bu dillerden ikisinin derslerine devam etmek mecburiyetindeydiler. Bunlardan birini okuyup yazabilecek derecede öğrendiklerini yapılan sınavlarda kanıtlamaları gerekiyordu. ${ }^{13}$ Bedi Bey, Leyli Tip Talebe Yurdu'ndaki bu dersler sayesinde Fransızca ve İngilizce öğrendi.

29 Teşrinievvel (Ekim) 1934 tarihinde Tıp Fakültesi öğrenci kimliğini aldı ve derslere devam etmeye başladı. Bir yandan da Kumkapı Assompsiyon Fransız Okulu'nda Türkçe (1 Ekim 1933-30 Eylül 34), Gaziosmanpaşa Ortaokulu'nda Tabiiyye (Biyoloji) (1936-37), Taksim Erkek Lisesi'nde Tabiiyye (1938-39) dersleri vermekteydi.

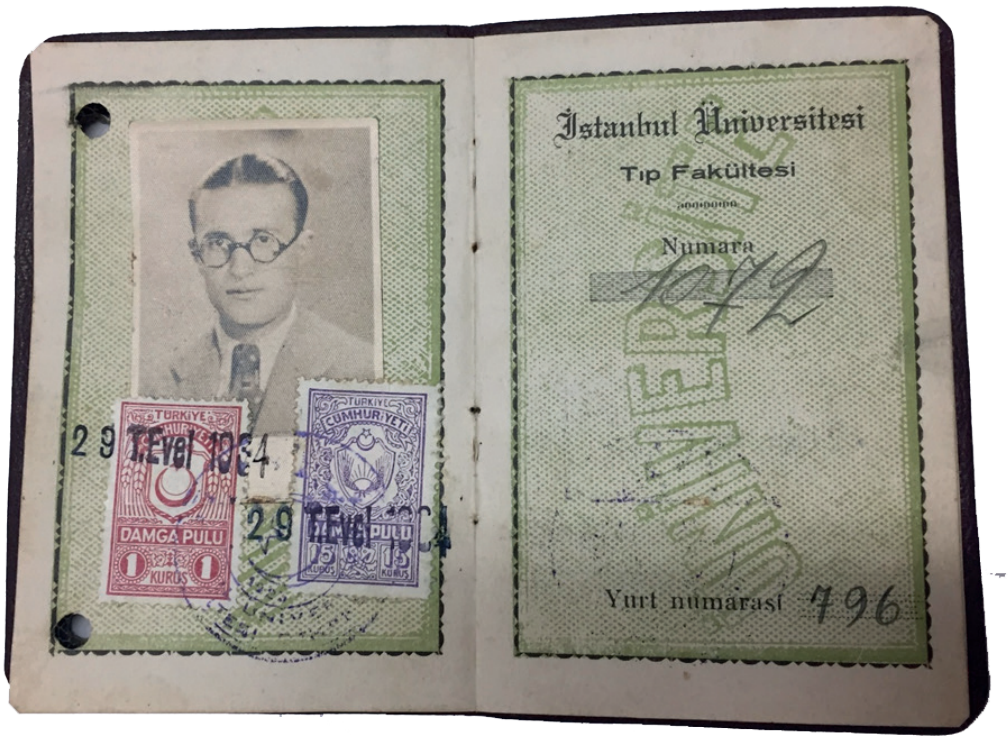

Bedi N. Şehuvaroğlu'nun İstanbul Üniversitesi Tıp Fakültesi öğrenci kimliği, 29 Teşrinievvel (Ekim) 1934 (İstanbul Üniversitesi İstanbul Tıp Fakültesi Öğrenci Arşivi, İsmail Bedi Nuri Ef., Şahsuvaroğlu dosyasi).

T.C. Milli Müdafaa Vekâleti, Üniversite Talim Taburu Komutanlığı'nın 1490 sayılı yazısından anlaşıldığına göre, 1934-35 ve 1935-36 ders yıllarında, D. 60 Sayılı Askerliğe Hazırlık Talimatı uyarınca, taburda yüksek ehliyetnâme eğitimini takip etmiş, sınavda başarılı olması üzerine adına Yüksek Ehliyetname düzenlenmişti (1936). ${ }^{14}$

13 T.C. Sıhhat ve İçtimai Muavenet Vekâleti Tıp Talebe Yurdu Müdürlüğü, Tıp Talebe Yurdu Dahili Talimatnamesinden Talebeyi Alâkalandıran Bazı Maddeler (İstanbul: Matbaa-yı Ebüzziya, 1933), 73. madde.

141 Haziran 1935'te güncellenen bu talimata göre; orta ve yüksek tahsil çağında bulunan gençler, İhtiyat Subay ve Ihtiyat Askeri Memurları Kanunu uyarınca askeri ehliyetname almak zorundaydılar. Bunun için kendi okullarının programlarına konulan askeri derslere, talimlere ve yıllık kamplara katılmaları gerekiyordu. Günseli Gümüşel, “Erkekler İçin Askerliğe Hazırlık Dersleri,” Çanakkale Araştırmaları Türk Yıllığı 15, 22 (Bahar 2017): 1-40. 
Öğrenci dosyasında yer alan, 3 Ağustos 1939 tarihli belge o yıllarda Tıp Fakültesi’ndeki derslerin hâlâ doktora usulüne göre yürütüldüğünü göstermektedir. İsmail Bedi Nuri Şehsuvaroğlu'nun notları şöyledir:

1.Doktora: Kimya, Orta; Histoloji, Pekiyi; Fizyoloji, Orta; Teşrih, Orta.

2.Doktora: Umumi emraz, İyi; Mikrobiyoloji, Orta.

3.Doktora: Hıfzıssıhha, İyi; Marazi teşrih, Orta; Tıp Müfredatı, İyi.

4.Doktora: Dahiliye, İyi; Hariciye, Pekiyi; Çocuk, Pekiyi; Doğum ve Kadın, Pekiyi; Akıl, Pekiyi; Deri ve Frengi, Pekiyi; İnkılap, Geçer.

$\mathrm{Bu}$ dersleri Neş'et Ömer İrdelp, Mazhar Osman Uzman, Cevat Kerim İncedayı, Hulusi Behçet, İhsan Hilmi Alantar, Âkif Şakir Şakar, Ahmet Kemal Atay, Kemal Cenap Berksoy, Tevfik Remzi Kazancıgil gibi Türk tıbbının en yetkin ve alanlarında öncülük yapmış hocalardan ve 1933 Üniversite Reformu ile gelen Alman profesörler Frank, Nissen, Braun, Schwartz, Hirsch, Winterstein, Igersheimer, Liepmann, Oberndorfer, Heillman gibi profesörlerden almıştı.

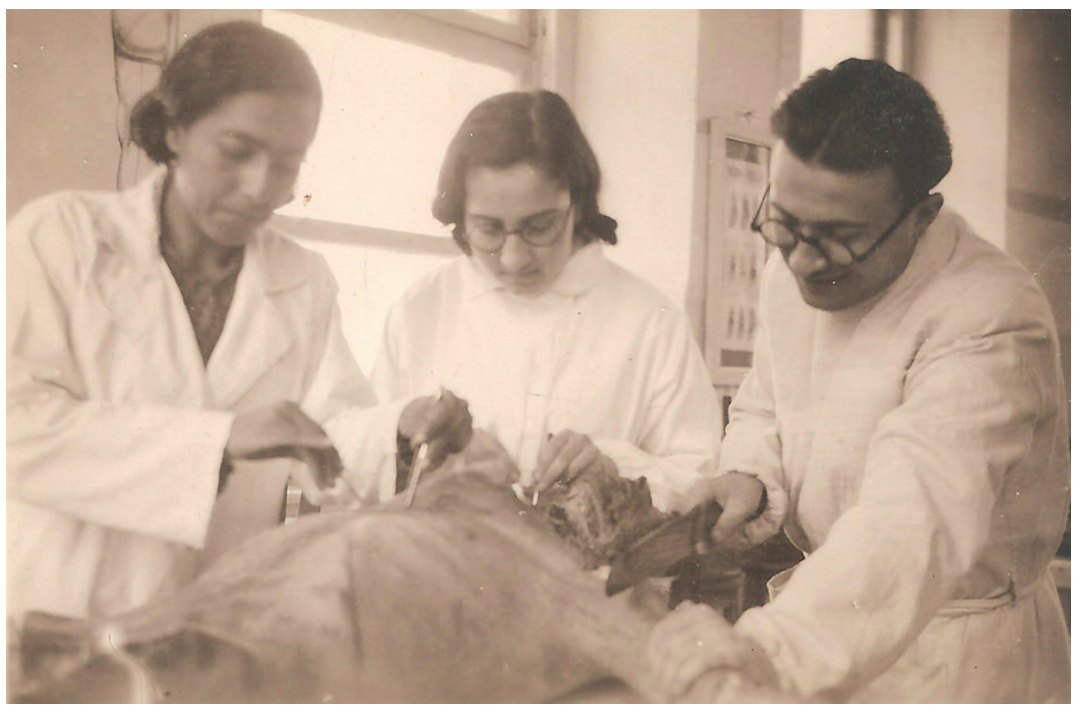

Bedi N. Şehsuvaroğlu, İstanbul Üniversitesi Tıp Fakültesi teşrihhanesinde kadavra başında, 1934 (Selami Ahmet Şehsuvaroğlu Arşivi).

Öğrenci dosyasında bulunan Leyli Tıp Talebe Yurdu Müdürü Dr. H. Enver Sarp'ın, 13 Mayıs 1939 tarih ve 1496 sayılı yazısından anlaşıldığına göre, mezuniyetine az bir zaman kala, 13 Şubat 1939 tarihinde kendi isteği ve Sihhat Vekâleti'nin izniyle Leyli Tıp Talebe Yurdu'ndan ayrılıp Tıp Fakültesi'ne nehari (gündüzlü) olarak devam etmiştir. Bundan birkaç ay sonra, 26 Haziran 1939'da mezun olup askere gitti (dipl. no. 1690/5158). Askerliğini Kayseri 19. Piyade Alayı'nda yedek tabip üsteğmen olarak yaptı (17 Ekim 1939-15 Kasım 
1941). Leyli Tıp Talebe Yurdu'nda kaldığı için mecburi hizmeti vardı. Terhis olur olmaz Eskişehir Sıtma Mücadele Riyaseti Şubesi tabipliğine olarak tayin edildi (13 Aralık 1941-19 Eylül 1943). İstanbul'da çıkan tifüs salgınıyla mücadele için kurulan Tifüs Mücadele Heyeti ile birlikte İstanbul'a geldi (1943). Mücadele bitince İstanbul'da kalarak Merkez Hükümet Tabibi oldu (Eylül 1943).

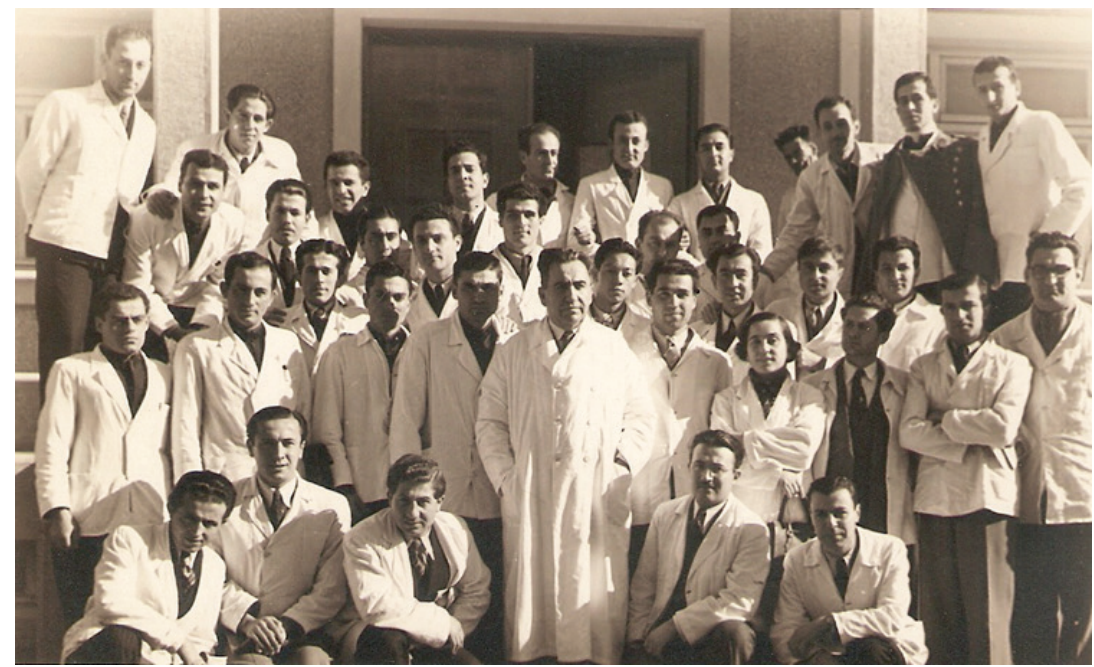

Bedi N. Şehsuvaroğlu, psikiyatri stajında Mazhar Osman Uzman ile, 18 Ocak 1937 (Selami Ahmet Şehsuvaroğlu Arşivi).

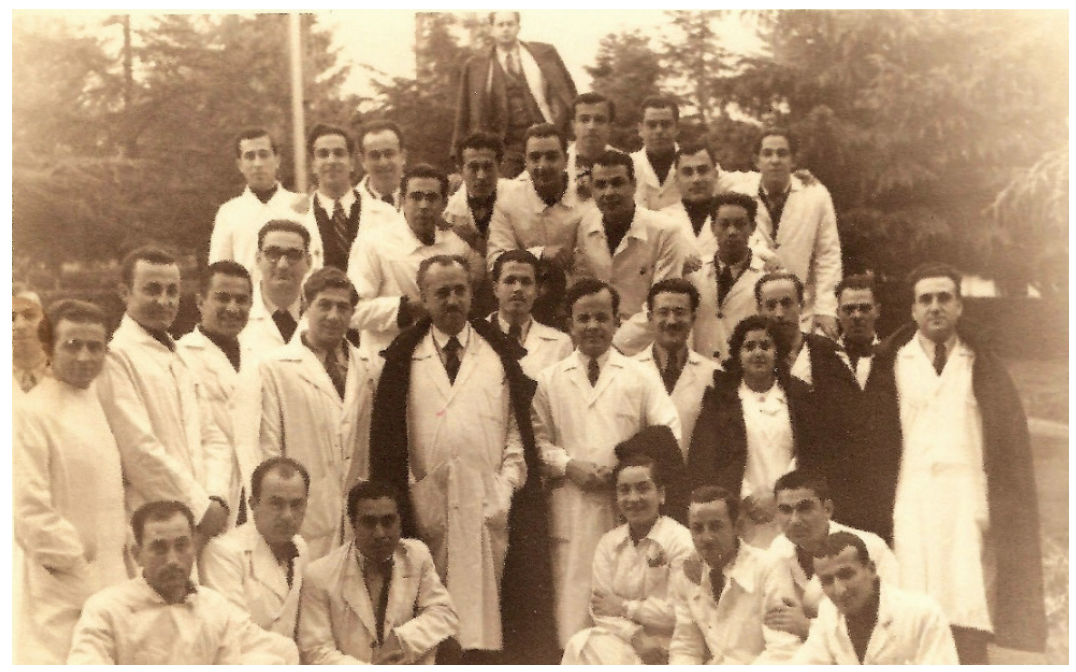

Şişli Etfal Hastanesi'nde çocuk stajında, hocaları İhsan Hilmi Alantar ve Şevket Salih Soysal ile, 23 Aralık 1938 (Selami Ahmet Şehsuvaroğlu Arşivi). 
İkinci Dünya Savaşı sırasında, Kartal 2. Tank Alay Tabibi olarak ikinci kez askerlik yaptı (1944-45). Daha sonra İstanbul Sağlık Müdürlüğü’ndeki görevine döndü. Hicaz'da patlak veren kolera salgınıyla mücadele için kurulan ekibin şefi olarak Hicaz ve Mısır'a gitti (1947). Dönünce, Hac Yolu (İstanbul: 1948) kitabını yayımladı. Sağlık ve Sosyal Yardım Bakanlığı 2. Sınıf müfettişliğine tayin edildi (14 Ağustos 1948).
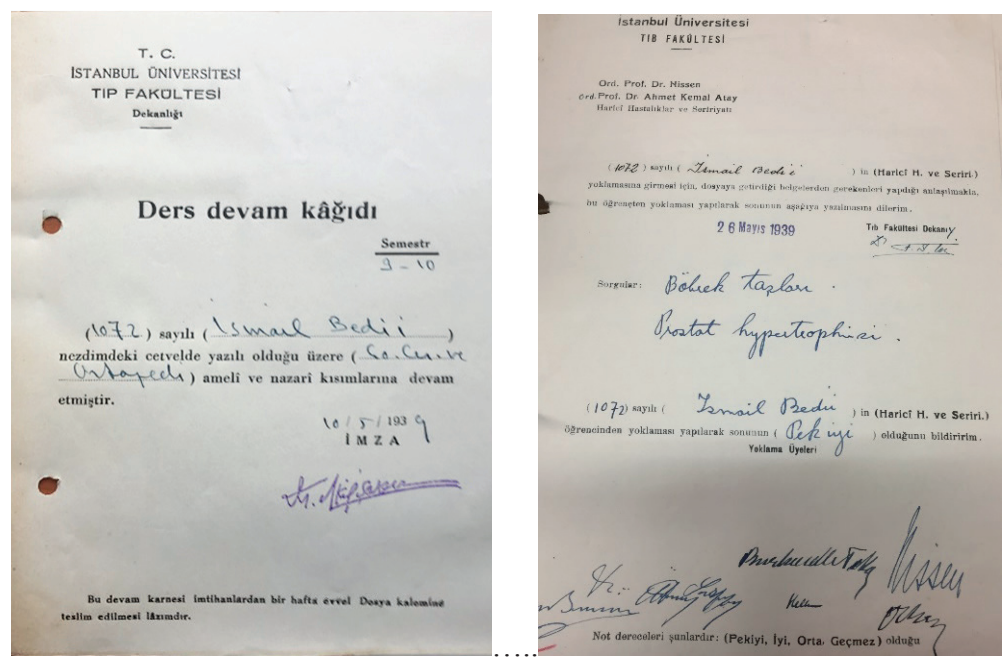

Bedi N. Şehsuvaroğlu'nun Akif Şakir Şakar imzalı, 9-10 sömestr Çocuk Cerrahisi ve Ortopedi dersine devam kâğıdı, 10 Mayıs 1939 (üstte solda) (İstanbul Üniversitesi İstanbul Tıp Fakültesi Öğrenci Arşivi, İsmail Bedi Nuri Ef., Şahsuvaroğlu dosyası); Harici Hastalıklar ve Seririyatı (Kliniği) sınavına dair, Prof. Dr. Nissen ve diğer hocaların imzasını taşıyan sınav sonuç belgesi, 26 Mayıs 1939 (üstte sağda) (İstanbul Üniversitesi İstanbul Tip Fakültesi Öğrenci Arşivi, İsmail Bedi Nuri Ef., Şahsuvaroğlu dosyas1).

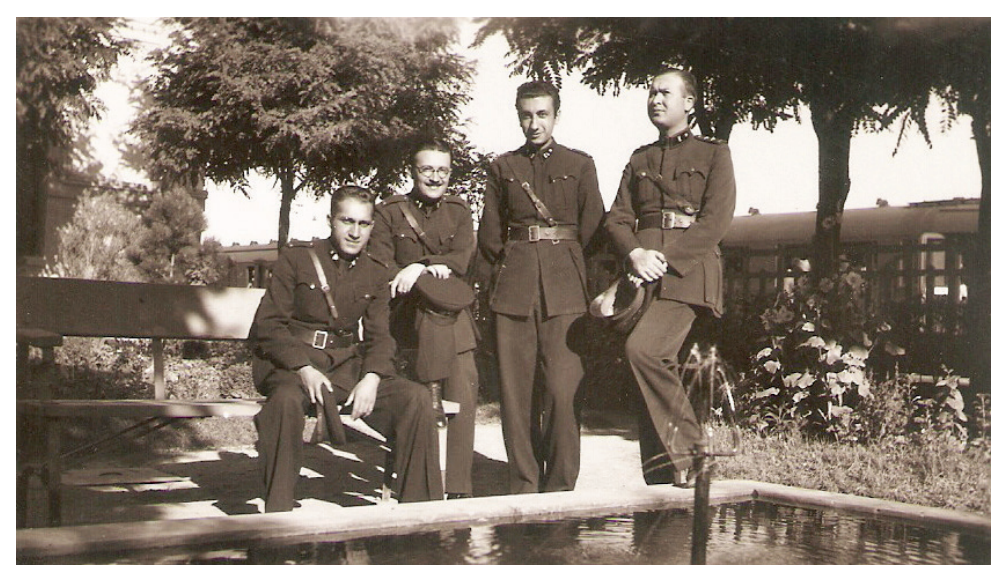

Bedi N. Şehsuvaroğlu (soldan ikinci) askerlik hizmeti sırasında Kayseri'de. 30 Temmuz 1940 (Selami Ahmet Şehsuvaroğlu Arşivi) 


\section{Akademik Hayatı}

Mesleğinin tarihine ilgisi, İstanbul'a gelir gelmez onu İstanbul Üniversitesi Tıp Fakültesi Tıp Tarihi Enstitüsü’ne sürüklemişti. Enstitü Direktörü Prof. Dr. Süheyl A. Ünver'in kütüphane araştırmalarına katılıp yardımcı olmaya başladı (1943). Tıp tarihine duyduğu ilgi ve sevgiden çok memnun kalan Dr. Ünver, Şehsuvaroğlu'nun Tıp Tarihi Enstitüsü'ne resmen fahri asistan olarak tayin edilmesini istediyse de Sağlık ve Sosyal Yardım Bakanlığı izin vermedi (1948). Rockefeller Vakfı bursuyla bir sömestre, Amerika Birleşik Devletleri'nde Harvard Halk Sağlığı Okulu'na devam etti (1949).

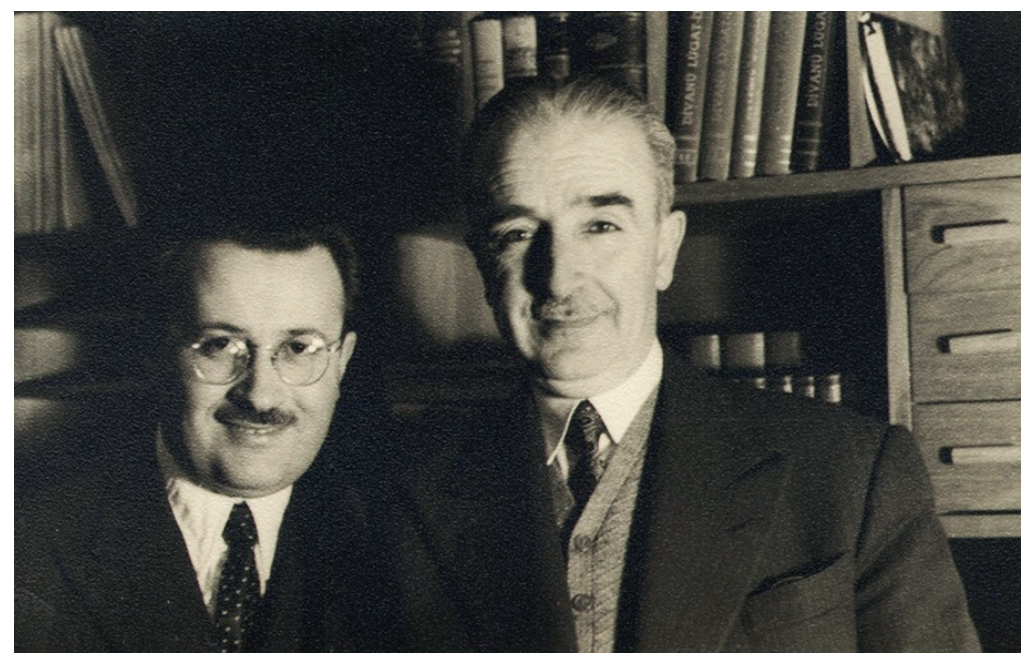

Doç. Dr. Bedi N. Şehuvaroğlu (solda), hocası Prof. Dr. A. Süheyl Ünver'in (sağda) 58. doğum gününde,

17 Şubat 1956 (İstanbul Üniversitesi-Cerrahpaşa, Cerrahpaşa Tıp Fakültesi Tıp Tarihi ve Etik Anabilim Dalı Arşivi).

Dr. Ünver'in 1srarlı girişimleri sonucu, Tıp Tarihi Enstitüsü’ne tahsis edilen, aday asistan kadrosuna tayin edildi (31 Ağustos 1950). Ertesi sene asil asistan kadrosuna geçti (1 Eylül 1951).

Tababet ve Şuabatı Sanatlarinın Tarzı İcrasina Dair Kanun'un (1219 sayıl1, 1928) 9. maddesi gereğince Sağlık ve Sosyal Yardım Bakanlığı tarafından yeniden hazırlanan, Tababet Uzmanllk Belgeleri Hakkinda Tüzük'te (24 Temmuz 1947) sayllmayan bilim dallarında uzman olmak isteyenler, Üniversiteler Капипи (18 Haziran 1946) hükümlerine göre bir yeterlilik sınavına girer, İstanbul Üniversitesi Tip Fakültesi Uzmanlık Imtihanı Yönetmeliği’ne göre bir uzmanlık tezi hazırlar, tezin kabulünden sonra uzmanlık sinavina girerlerdi. ${ }^{15}$ Tıp Tarihi, adı geçen tüzükteki bilim dalları arasında yer almadığı için, bu

15 Tıp Tarihi, 2 Haziran 1961 gün ve 5/1276 sayılı Tababet İhtisas Tüzüğü’nü tadil eden 13 Ekim 1961 gün ve 5/1789 sayılı kararla (Resmi Gazete, sayı. 10942) ihtisas dalı kabul edilmiş olup, 1962'de yürürlüğe giren Tababet Uzmanlık Tüzüğü'nde uzmanlıklar arasına alınmıştır. 
aşamalardan geçen Şehsuvaroğlu'nun uzmanlık tezi, Prof. Dr. A. Süheyl Ünver, Ord. Prof. Dr. Kazım İsmail Gürkan ve Ord. Prof. Dr. İhsan Şükrü Aksel'den oluşan jüri tarafından başarılı bulundu, 7 Mart 1953 günü girdiği uzmanlık sınavını da başarınca ilk "Tıp Tarihi Uzmanı" oldu (uzmanlık no. 10054/4078). Uzmanlık tezi, Şair ve Hekim Ahmedi, Hayatı ve Eserleri (İstanbul, 1954) adıyla yayınlandı.

Uzman olduktan sonra hemen, karantina tarihiyle ilgili doçentlik tezini hazırlamaya başladı. Doçentlik jürisinin başkanı Ord. Prof. Dr. A. Süheyl Ünver idi. Ankara Üniversitesi Tıp Tarihi Enstitüsü Direktörü Prof. Dr. Feridun Nafiz Uzluk raportör tayin edilmişti. Ankara Üniversitesi Tıp Fakültesi Mikrobiyoloji Enstitüsü'den Dr. Vefik Vassaf Akkan, İstanbul Üniversitesi Tıp Fakültesi'nden Ord. Prof. Dr. İhsan Şükrü Aksel, Ord. Prof. Dr. Kazım İsmail Gürkan da üye olarak görevlendirilmişti. O yıllarda doçentlik tezi kabul edildikten sonra kolokyum sınavı yapılırdı. Şehsuvaroğlu tezi kabul edildikten sonra, "Osmanlı Tababetinde Batılılaşma Akımları" konulu deneme dersini 5 Kasım 1955 Cumartesi günü başarıyla tamamlayıp, eylemsiz doçent oldu (5 Kasım 1955). Ertesi sene de doçent kadrosuna atandı (29 Şubat 1956). Doçentlik tezi, Türkiye Karantina Tarihine Giriş adıyla dört bölüm olarak, İstanbul Üniversitesi Tıp Fakültesi Mecmuası'nda yayımlandı (I. Bölüm: 1957, 3-28, II. Bölüm: 1957, 601-609. III. Bölüm: 1958, 148-149. IV. Bölüm: 1959, 322-323).

Türk Tıp Tarihinin öncülerinden A. Süheyl Ünver, Tedavi ve Farmakodinami doçenti bulunduğu sırada, Tıp Tarihi ve Deontoloji Kürsüsü'ne geçmiş ve bu alanda kendi kendini yetiştirmişti. Şehsuvaroğlu ise hekimliği bırakıp, Tıp Tarihi ve Deontoloji Kürsüsü’ne asistan olarak girmekle A. Süheyl Ünver'in öğrencisi olmuştur. Uzmanlık ve doçentlik tezlerini Süheyl Ünver'in yönlendirmesiyle hazırlarken hocasının araştırma yönteminden etkilenmiş olmakla beraber, zamanla kendi tarzını geliştirmiştir. Süheyl Ünver, genellikle, “Türkiye'de eter narkozunun tarihçesi" (Modern Tedavi Mecmuası, 1/I (1951):13-14) makalesinde olduğu gibi, kısa makalelerle bir konunun önemini vurgulayıp yol gösterici olmuştur. ${ }^{16}$ Şehsuvaroğlu'nun, hocasının tarzına uygun makaleleri yanında, kapsamlı ve sistematik makaleleri de vardır.

Şehsuvaroğlu, profesörlüğe yükseldikten (14 Haziran 1962) birkaç yıl sonra İstanbul Üniversitesi Tıp Fakültesi, Cerrahpaşa Tıp Fakültesi ve İstanbul Tıp Fakültesi olmak üzere resmen ikiye ayrıldı (Eylül 1967). Prof. Dr. A. Süheyl Ünver Cerrahpaşa Tıp Fakültesi’ne geçti. Bir süre aynı çatı altında eğitime devam edildi. 1970 yılında iki fakülte fiilen ayrılınca Süheyl Ünver, bir tatil günü Tıp Tarihi Enstitüsü demirbaşına kayıtlı el yazmalarının tamamını, kütüphanedeki kitapların çoğunu, ${ }^{17}$ Feyhaman Duran'ın yağlıboya tablolarını ve

16 Ünver'in hayatı ve çalışmaları hakkında bkz. Ahmet Güner Sayar, A. Süheyl Ünver: Hayatı, Şahsiyeti ve Eserleri (1898-1986), 4. bs. (İstanbul: Ötüken Neşriyat, 2016).

17 Enstitüye girdiğimde, Bedi Şehsuvaroğlu'nun bana verdiği ilk görev, kütüphanedeki kitapların künyelerini çıarmak olmuştu. Kütüphanenin kartoteks dolabı Cerrahpaşa'ya götürüldüğünden kalan kitaplar bilinmiyordu. Bütün kitapları elden geçirip künyelerini çıkardım ve listeledim. Daha sonra tayin edilen Kütüphaneci Servet Küçük bu listeyi kitaplarla karşılaştırarak fişledi. 
daha pek çok tarihi eser ile mobilyayı bir kamyona yükletip götürmüştür. ${ }^{18}$ Enstitüde 26 Ekim 1970 günü göreve başladıktan birkaç gün sonra, Süheyl Ünver'in gönderdiği bir elemanın Tıp Tarihi Enstitüsü’ne ait odaların kapılarındaki tabelaları sökmeye çalıştığına tanık oldum. Güvenlik güçleri bu girişimi engelledikten sonra, Prof. Dr. Bedi N. Şehsuvaroğlu'nun demirbaşların iadesi için resmi yollara başvurması üzerine, yıllardır sürmekte olan saygı ve sevgiye dayalı hoca-öğrenci ilişkisi dargınlıkla sona ermiş, Şehsuvaroğlu'nun vefatına kadar hiç görüşmemişlerdi. Şehsuvaroğlu, bu ayrılmanın ardından topladığı el yazması Türkçe tıp eserleri, Arap harflerle basılmış Türkçe tıp kitapları, arşiv ve müze materyali ile Tıp Tarihi Enstitüsü’nden götürülen varlıkların boşluğunu doldurmaya çalışmıştır.

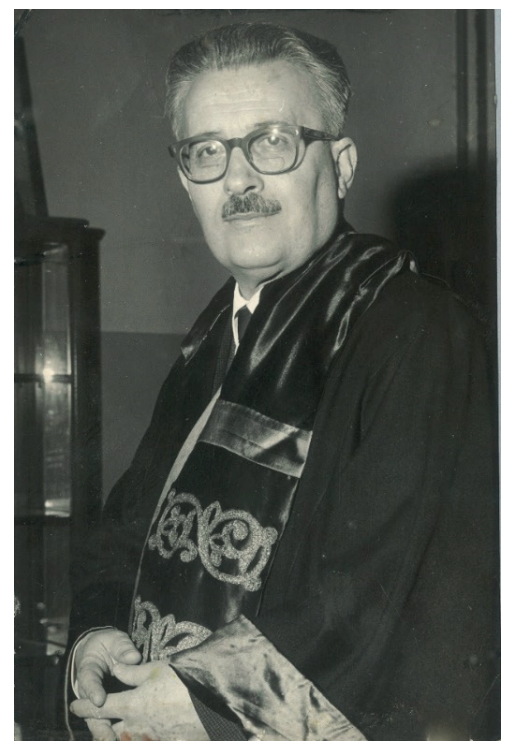

Bedi N. Şehsuvaroğlu profesör cübbesiyle (Selami Ahmet Şehsuvaroğlu Arşivi).

1970’ten sonra İstanbul'daki Türk Tıp Tarihi çalışmaları, Cerrahpaşa ve İstanbul Tıp Fakülteleri olmak üzere iki merkezde yürütülmüştür. Aynı zamanda ressam ve hattat olan Süheyl Ünver, Cerrahpaşa'da tıp tarihi yanında Türk süsleme sanatına önemli katkılarda bulunmuş, açtığı Nakışhane'de; hat, tezhip, minyatür, kâtı' sanatlarını öğreterek, Osmanlı nakışhane geleneğini yaşatmıştır. ${ }^{19}$ A. Süheyl Ünver ile Bedi N. Şehsuvaroğlu’nun İstanbul Tıp Fakültesi ile Cerrahpaşa Tıp Fakültesi’nde yetiştirdikleri öğrencilerin çalışmaları ayrıca

18 İstanbul Tıp Fakültesi Tıp Tarihi ve Deontoloji Anabilim Dalı demirbaşına kayıtlı olan bu eserler, daha sonra kurulan Cerrahpaşa Tıp Fakültesi Tıp Tarihi Müzesi’nin temelini oluşturmuştur. İstanbul Tıp Fakültesi Tıp Tarihi ve Etik Anabilim Dalı varlıklarının demirbaş kaydı yapılırken (2011), Anabilim Dalı Başkanı, eski demirbaş kayıtlarının bir kopyasını İstanbul Üniversitesi Rektörlüğüne gönderip, Cerrahpaşa’ya götürülen kıymetli tabloları geri istemişse de, bu tablolar üniversiteye bağlı bir fakültede bulunduğu gerekçesiyle iade edilmemiştir.

19 A. Süheyl Ünver'in katkıları için bkz. Ceylan Akgün Karaata, “Ord. Prof. Dr. Ahmet Süheyl Ünver'in Türk Süsleme Sanatı Eğitimine Katkıları” (Yüksek Lisans Tezi, Gazi Üniversitesi Eğitim Bilimleri Enstitüsü, 2006). 
incelenmesi gereken bir konudur. Şehsuvaroğlu, Eylül 1967'de atanmış olduğu İstanbul Tıp Fakültesi Tıp Tarihi ve Deontoloji Kürsüsü kürsü profesörlüğü (başkanlığı) görevini vefatına kadar sürdürmüştür (1977).

\section{Eğitim-Öğretim Faaliyetleri}

Şehsuvaroğlu, çocuk yuvalarından üniversiteye kadar, örgün ve yaygın eğitime çok önem verirdi. 1946'da hizmete giren Çocuk Yuvaları Derneği'nin kurucu üyelerindendi, başkanlığında da bulundu. Bu derneğe bağlı çocuk yuvaları, çalışan kadınların 3-7 yaş çocuklarını kabul ediyordu. Şehsuvaroğlu iki çocuk yuvasının fahri reisliğini, müdürlüğünü ve kuruculuğunu üstlenmiştir.

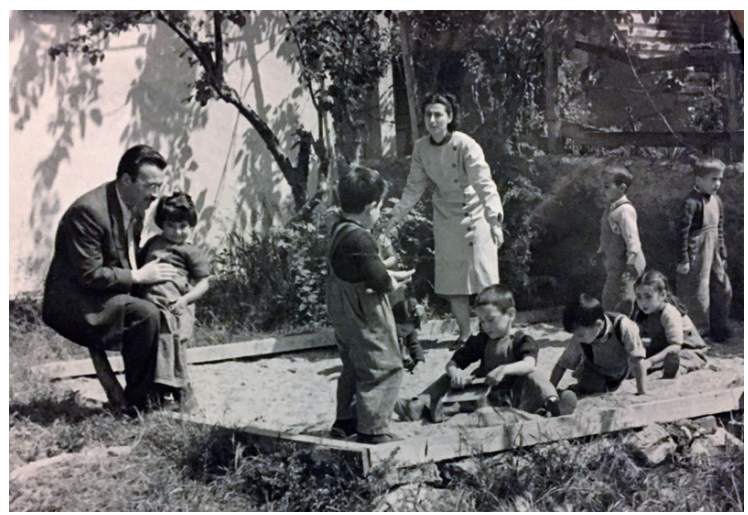

Bedi N. Şehsuvaroğlu, Çocuk Yuvaları Derneği’nin bir yuvasında çocuklarla, 1946 (Selami Ahmet Şehsuvaroğlu Arşivi ).

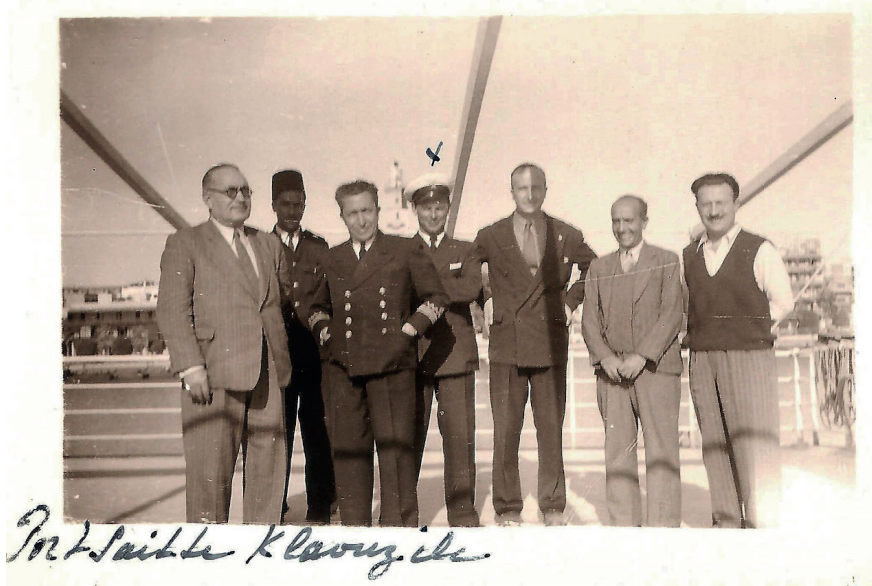

Bedi N. Şehsuvaroğlu (sağ başta), Sağlık Bakanlığı Kolera Mücadele Ekibiyle Port Said'de, 1947 (Selami Ahmet Şehsuvaroğlu Arşivi) 
Üniversiteye geçtikten sonra İstanbul Tıp Fakültesi'ndeki derslerini vefatına kadar sürdürmüştür. Yanında çalıştığım 1970-1977 yıllarında teorik Tıp Tarihi ve Deontoloji derslerini fakültenin Çapa yerleşkesindeki amfide anlatır, ayrıca sınıfı gruplara bölüp her grup için haftada bir gün kürsüde seminer yapard1. Seminerlerden önce öğrencilere müzeyi gezdirir ve sergilenmekte olan tıp ve sağlık tarihine ilişkin objeler hakkında bilgi vererek tıp tarihini sevdirmeye çalışırdı. Her seminerde deontolojik/etik bir sorunu gündeme getirir, öğrencileri tartıştırırdı. Öğrenciler açık oturum şeklinde geçen bu derslerden memnun olarak ayrilırlard1.

İlk yayınları arasında yer alan, "Harp Suçlusu Alman Hekimler", "Hekimliğin Dertleri”, "Hekim ve Cemiyetin Karşılıklı Vazifeleri”, "Sır, Yalan ve Hakikat Karşısında Hekim”, "Hekimin Hukuki Mesuliyeti”, "Hekim Yemini”, "Çocuk Düşürme”, “Türkiye’de Sağlık Davaları ve Hekim Dertleri”, "Tibbi Sorumluluk", “Organ Nakli ve Tıp Ahlakı" konularını" yıllar içinde geliştirerek, Tıbbi Deontoloji Dersleri (İstanbul, 1975) kitabına almıştır. Tıbbi deontoloji konusunda Türkçe yazılmış ilk kitaptır. ${ }^{21}$ Dikkate değer diğer bir özelliği de insanlarda doku ve organ nakli, nüfus planlaması, yapay döllenme, insan üzerinde deneyler, ötanazi gibi uygulamaların içerdiği etik sorunları müfredata sokmuş olmasıdır. Şehsuvaroğlu organ nakillerinde hukuk, etik ve ahlâkın önemine şu ifadeyle dikkat çekmiştir:

Tekniği kuvvetli cerrahların iddialarına göre, yüzyıl bitmeden beyin ve omurilik hariç, insanın bütün organları nakledilebilecektir. Belki onlar da nakledilebilecekler, ortaya şahsiyet gibi, hatta şahsın kendisine karşı kanun tarafından korunan, bir varlık çıktığı için cerrahlar bu son nakillere cesaret edemeyeceklerdir. Yani onların elini teknik değil, hukuk, etik ve genellikle ahlâk bağlayacaktır. ${ }^{22}$

Tıbbi Deontoloji kitabı bunlardan başka tıbbi mevzuat, uyuşturucu maddeler, hibernasyon, sağlık hizmetlerinin sosyalleştirilmesi, örnek hekimler bahislerini içermektedir. Sonraki yıllarda tüp bebek ve bazı tıbbi mevzuatın eklenmesiyle 2004 yılına kadar ders kitabı olarak kullanılmıştır. ${ }^{23}$

20 Bu konulardaki makalelerinin kaynakları için bkz. Çağan, Bedi N. Şehsuvaroğlu Biyografi ve Bibliyografyası II, 97-99.

21 Ülkemizde, ilk deontoloji ders kitabı Nurican Efendi (Dr. Joseph Nouridjan) tarafindan Fransızca olarak yazılmıştır: Précis de Déontologie médicale. Cours elémantaire professé à l'Ecole impériale de Médecine de Constantinople (Constantinople: 1877). A. Süheyl Ünver tarafindan yazılmış olan Tibbî Deontoloji Derslerinden Kısa Bahisler (İstanbul, 1946) ise kitap sayılamayacak kısalıkta (21 s.) bir yayındır.

22 Bedi N. Şehsuvaroğlu, Tibbi Deontoloji Dersleri (İstanbul: Hüsnütabiat Matbaası, 1975), 90.

23 Bedi N. Şehsuvaroğlu, Tibbi Deontoloji, yay. haz. Arslan Terzioğlu (İstanbul: İstanbul Tip Fakültesi Vakfi, 1983). Türkiye'de Tip Tarihi ve Deontoloji öğretimi için bkz. Şehsuvaroğlu, Bedi N., "Memleketimizde Tip Tarihi ve Deontoloji Öğretimi ve İstanbul Tip Fakültesi Tip Tarihi Enstitüsü," İstanbul Üniversitesi Tip Fakültesi Mecmuası 32 (1970): 368-375; Nuran Yıldırım ve Yeşim Işı1 Ülman, "Başlangıcından Günümüze İstanbul Üniversitesi'nde Tıp Tarihi ve Deontoloji Eğitimi Tarihine Bir Bakış," Uluslararası Katılımlı 3. Ulusal Tıp Etiği Kongresi Kongre Kitabı içinde, ed. Ayşegül Demirhan Erdemir, İlter Uzel, Öztan Öncel, Oğuz Y. Aksoy ve diğerleri (Bursa: F. Özhan Matbaacılık San. Ltd. Şti., 2003), 1109-1116. 
1970’li yıllarda tıp tarihi derslerine esas olmak üzere, Türk Tıp Tarihi kitabı yazmaya girişmişti. Türk Tıp Tarihi’nin geçirdiği evreleri yüzyıllara göre ele alarak iz bırakan hekimler ve eserleri, darüşşifalar-hastaneler ve diğer sağlık kurumlarıyla kapsamlı bir eser tasarlamıştı. Esere girecek bazı konuların ön araştırmalarını o konuyla ilgili eğitim almış kürsü çalışanlarına yaptırırdı. Eczacılık ve ilaç konularını eczacı arkadaşımıza, darüşşifaları sanat tarihçisi arkadaşımıza, Türkçe yazma tıp kitaplarını da bu satırların yazarına vermişti. Toparladığımız bilgileri kendisine verirdik. El yazısıyla yazdığı kitap bölümlerini daktiloda üç nüsha olarak yazdırırdı. Eserini tamamlamak üzereyken vefat edince yazdığ 1 kadarı, iki kürsü çalışanının (A. E. Demirhan ve G. C. Güreşsever) girişimi ve eşinin izniyle yayınlanmıştır: Türk Tıp Tarihi (Bursa: Taş Kitapçılık-Yayıncılık,1984).

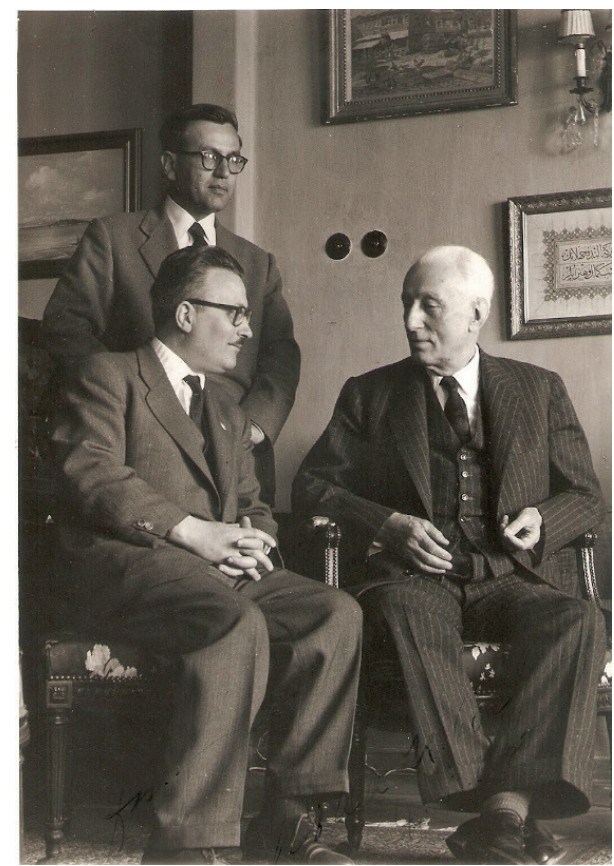

Bedi N. Şehsuvaroğlu, Türkiye'de hidroklimatolojinin kurucusu Ord. Prof. Dr. Nihat Reşat Belger (18821961) ve Türk eczacılık tarihi çalışmalarının öncülerinden Doç. Dr. Turhan Baytop (1920-2002) ile. (Selami Ahmet Şehsuvaroğlu Arşivi)

1955 yılında, İstanbul Üniversitesi Senatosu'nun kararıyla, o yıllarda Tıp Fakültesi’ne bağlı olan Eczacılık Okulu ile Dişhekimliği Yüksekokulu'nda "Meslek Tarihi ve Meslek Ahlakı” derslerini üstlendi. ${ }^{24}$ Süheyl Ünver 1938-1954 yıllarında Eczacılık Okulu’nda bu dersi

24 O yıllarda İstanbul Üniversitesi Tıp Fakültesi’ne bağlı olan Eczacı Okulu, Tıp Fakültesi Profesörler Kurulu’nun 4 Şubat 1961 tarihli oturumunda aldığı kararın İstanbul Üniversitesi Senatosu'ndan geçtikten sonra 15 Ocak 1962'de Milli Eğitim Bakanlığı tarafından onaylanması üzerine 15 Ocak 1962'de İstanbul Üniversitesi Eczacılık Fakültesi adıyla bağımsız bir fakülte olmuştur. İstanbul Üniversitesi Eczacılık Fakültesi 1962- 
Tıp Fakültesi öğrencileriyle birlikte yapardı. Şehsuvaroğlu farklı ders programları hazırladı. Eskiden beri devam zorunluluğu olan fakat sınavı olmayan bu derse, Eczacılık Fakültesinin kurulmasından sonra sınav mecburiyeti koydurdu (1964). Eczacılık Fakültesi son sınıf öğrencilerine birer Bitirme Tezi hazırlatarak meslek tarihlerini daha yakından öğrenmelerini sağladı. ${ }^{25}$ Eczacılık Okulu, fakülte olunca açılış töreninde, "Türkiye'de eczacılık öğretiminin geçirdiği safhalar" başlığıyla fakülte açılış dersini verdi (4 Kasım 1963). Vefatına kadar 22 sene boyunca anlatmış olduğu dersleri genişletip kaleme aldığı, Eczacılık Tarihi Dersleri (İstanbul, 1970), araştırmacıların da yararlandığı kapsamlı bir eser olup ülkemizin ikinci eczacılık tarihi kitabıdır. ${ }^{26}$

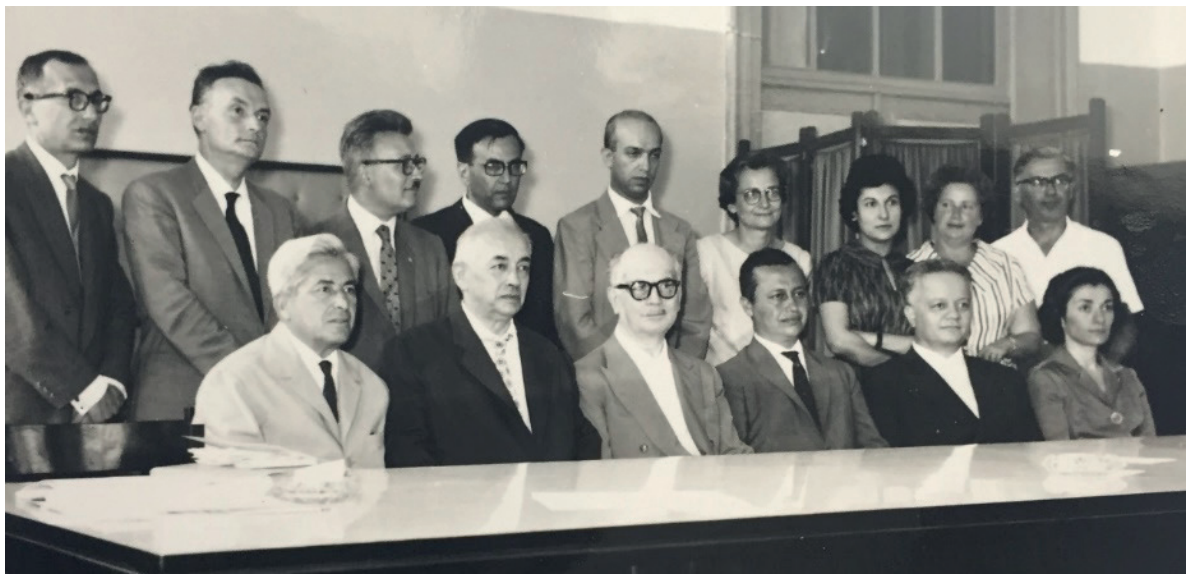

İstanbul Üniversitesi Eczacılık Fakültesi'nin dekan ve kurullarını seçmek için 17.10.1963’te toplanan ilk profesörler kurulunda Bedi N. Şehsuvaroğlu (arka sıra soldan üçüncü)

(Selami Ahmet Şehsuvaroğlu Arşivi).

Kurul üyelerinin isimleri için bkz. Turhan Baytop, Türk Eczacılık Tarihi

(İstanbul: İstanbul Üniversitesi Eczacilık Fakültesi, 1985), 351.

Ege Üniversitesi kurulurken, Tıp Fakültesi'nin kurucu dekanlığı İstanbul Üniversitesi Tıp Fakültesi’nden Ord. Prof. Dr. Muhiddin Erel'e verilmişti (1955). Dr. Erel, “Tıp Tarihi ve Deontoloji” dersini vermek üzere Şehsuvaroğlu'nu davet etti. 1956-1958 yıllarında, misafir öğretim üyesi olarak iki sene Tıp Tarihi ve Deontoloji derslerini üstlenen Şehsuvaroğlu, "Egede İlmin ve Tababetin Gelişmesi” hakkındaki Ege Üniversitesi açılış dersini vermiş (9 Mart

2002, haz. T. Baytop, A. Mat, N. Akev, E. İlhan, ve Y. Ö. Erginer (İstanbul: [yayl. y.], 2002), 9. Dişhekimliği Yüksekokulu da 11 Temmuz 1964 'te Tıp Fakültesi’nden ayrılarak İstanbul Üniversitesi Dişhekimliği Fakültesi olmuştur. Ahmet Efeoğlu, Dişhekimliği Tarihi (İstanbul: İstanbul Üniversitesi, 1992), 129.

25 Bedi N. Şehsuvaroğlu, Eczacllık Tarihi Dersleri (İstanbul: İstanbul Üniversitesi Eczacılık Fakültesi, 1970), 9. Bu kitabının önsözünde, "bazı çok orijinal bitirme tezleri ile" çalışmalarına ş̧ı tutan öğrencilerine teşekkür etmiştir. Eczacılık Okulu'nda yaptırdığı bitirme tezlerinin bir kısmı İstanbul Tıp Fakültesi Bedi N. Şehsuvaroğlu Arşivi’ndedir.

26 İlk kitap iki sene önce yayınlanmıştır; Naşid Baylav, Eczacllık Tarihi (İstanbul: Yörük Matbaası, 1968). 
1956) ${ }^{27}$ ardından ilk Tıp Tarihi ve Deontoloji dersini Bergama Asklepionu'nda anlatmıştı (13 Mart 1956). Türkiye'nin üçüncü üniversitesinin kuruluş aşamalarını iki yayını ile tarihe mal etmiştir: "Ege Üniversitesi'nin Açılışı” (İstanbul Üniversitesi Tıp Fakültesi Mecmuası, 2, 19 (1956): 246-248) ve Ege Üniversitesi Açılış Hatırası (İstanbul: Yeni Türkiye Matbaası, 1957).

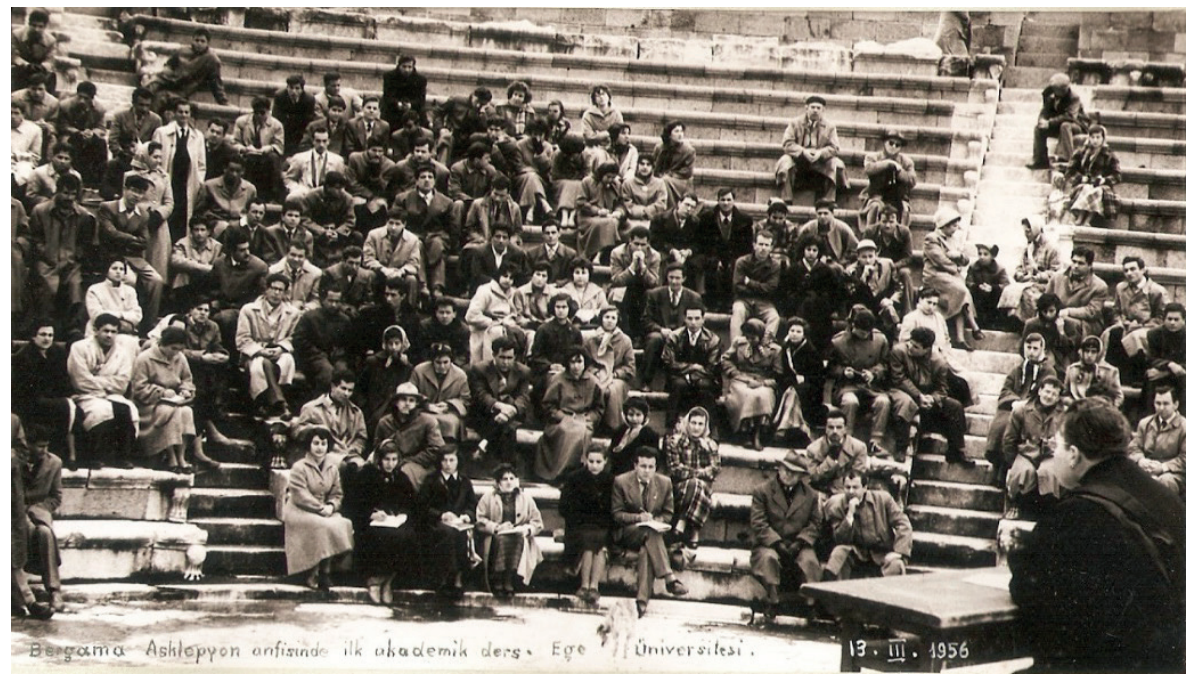

Ege Üniversitesi Tıp Fakültesi'nin ilk Tıp Tarihi ve Deontoloji dersini verirken. Bergama Asklepionu, 13 Mart 1956 (Selami Ahmet Şehsuvaroğlu Arşivi).

1957'den itibaren İstanbul Gazetecilik Enstitüsü'nde ilimler tarihi üzerine seri konferanslar vermiş, ayrıca Şişli'de açılan ve daha sonra 1965'te Nişantaşı'na taşınan, Özel İstanbul Eczacılık Yüksek Okulu'nun "Meslek Tarihi ve Deontoloji” derslerini yürütmüştür (19631971). ${ }^{28}$ Diyarbakır Tıp Fakültesi ile Hacettepe Tıp Fakültesi’nde de dersler vermiş, Tahran Üniversitesi'nin daveti üzerine gittiği Tahran'da konferanslar vermiştir (12-19 Ekim 1974).

\section{Bilimsel Araştırmaları ve Yayınları}

Şehsuvaroğlu, İstanbul Üniversitesi Tıp Fakültesi Tıp Tarihi ve Deontoloji Kürsüsü’nde 1950-1977 yılları arasında çalıştı̆̆ 27 senede; tıp tarihi, deontoloji, eczacılık, diş hekimliği, bilim ve kültür tarihi alanlarında irili ufaklı, 40 kitap ile 500'ü aşkın makale yayınlar. Tıp tarihine yönelik yayınlarının en önemli özelliği, tarihe mal olmuş tıbbi olayları hekim gözüyle değerlendirip yaşadığı dönemdeki gelişmelerle kıyaslayarak fikir yürütmesidir. Tıp tarihiyle

27 Çağatay Üstün, “Ege Üniversitesi Tıp Fakültesi’nin Eğitim ve Öğretime Başladığ1 9 Mart 1956 Günü Yapılan Konuşmalar ve Açılış Dersi Üzerine Bir Değerlendirme," İzmir'in Sağlık Tarihi Kongresi, 1-3 Aralık 2005, Bildiriler içinde, ed. Eren Akçiçek, Onur Kınlı (İzmir: Egetan Basın Yayın, 2009), 347-359.

28 Okul hakkında bkz., Marmara Üniversitesi Eczacılık Fakültesi'nin 50. Yllı, haz., Gülten Z. Omurtag, E. Dölen, M. Sancar, K. Elçioğlu, G. Erdoğan, ve E. T. Kocacık (İstanbul: Marmara Üniversitesi, 2013), 15-16. 
ilgili 229, deontoloji konularını içeren 35 ve ilimler tarihi hakkında 86 olmak üzere toplam 340 yayın yapmıştır. Burada Türk Tıp Tarihine katkı niteliğindeki yayınları ele alınacaktır. ${ }^{29}$

Bedi N. Şehsuvaroğlu, asistanlığa tayin olduktan sonra tıp tarihi araştırmalarına hız vermiş; İzmir-Bergama (Kasım 1951), Tavşanlı-Manisa-Kütahya-Bursa (Temmuz 1952), Bursa (Mayıs 1954), Manisa-İzmir-Tire (1957), Konya (Aralık 1958), Edirne (1960), Kayseri-Sivas-Tokat-Amasya (Ağustos 1961) araştırma gezilerine çıkmıştır. Bu şehirlerdeki darüşşifa, Asklepion gibi tarihi sağlık kurumlarını ve kütüphanelerindeki Şeriyye Sicilleri'ni ve el yazması tıp eserlerini incelemiştir. Milli Kütüphane (Ankara) ile İstanbul'daki çeşitli kütüphanelere ilaveten İspanya, Fransa, İtalya (1959), İngiltere (1964), İtalya ve Yugoslavya (1968) ve Romanya (1970) kütüphanelerinde yürüttüğü çalışmalar sonunda, bibliyografyalarda yer almayan, gün yüzüne çıkmamış yazma tıp kitaplarını bulup tanıtmıştır. İlk Türkçe tıp kitapları üzerindeki çalışmalarıyla hem Türk Tıp Tarihi’ne hem de Türk dili çalışmalarına katkılarda bulunmuştur. İlk Türkçe tıp kitaplarından koruyucu sağlıkla ilgili bir eserin tıpkıbasımını ve Latin harflerine çevrilmiş metnini yayınlamıştır: Eşref b. Muhammed: Hazâinü’s-saâdât, 1460 (H. 864). haz., Bedi N. Şehsuvaroğlu, Ankara: 1961) ile Cüzam ve Türkçe Tıp Yazmaları (A.S. Ünver ile, İstanbul: 1961) bu kapsamda yazılmış kitaplarıdır.

Bedi Şehsuvaroğlu, Harf Devrimi olduğunda (1928) 14 yaşındaydı. İlk öğrenimini Arap alfabesi ile tamamlamış, orta okuldayken Latin alfabesine geçmişti. Fakat Arap harflerini kullanma alışkanlığını terk etmemişti, notlarını Arap harfleriyle tutardı. Arap harfli Türkçe yazma ve basma tıp kitapları ile arşiv belgelerini okur ve anlardı. Hazâinü'ssaâdât'1, transkripsiyon sisteminin henüz yaygın olarak kullanılmadığı dönemde, Türkiye Türkçesinin yazım ve fonetiğine uygun olarak çevirirken, sadece Türkoloji eğitimi alanların vakıf olabildiği Eski Anadolu Türkçesi'nin gramer özelliklerini bilmediği için, o döneme ait kimi sözcükleri yanlış okumuştur. Ancak, bunlar metnin anlamını değiştiren yanlışlar olmayıp, eserin günümüz Türkçesine kazandırılarak içeriğinin araştırmacılara ulaşmasını engellememiştir. Nitekim, sonraları eseri dil açısından inceleyen bir doktora tezinde, Bedi Beyin Hazâinü s-saâdât çevirisi hakkında şu değerlendirme yapılmıştır: "Şehsuvaroğlu'nun çevirisi bazı okuma farklılıkları ve yanlışlıkları olmakla birlikte eserin faksimilesinin de çeviri ile birlikte yayınlanmasından dolayı Türk dili ve kültürü açısından takdir edilmesi gereken bir çaba ve çalışmadır." 30 Yakın zamanda Şehsuvaroğlu’nun yayınladı̆̆ı metin üzerinden yapılan bir araştırma da kaynak eser olduğuna işarettir. ${ }^{31}$

29 Dileğimiz, Türk Tıp Tarihine katkı niteliğindeki makalelerinin derlenip, notlandırılarak yeniden yayınlanmasıdır.

30 Nadir İlhan, "Eşref bin Muhammed Haza'inu's-Sa'adat (İnceleme-Metin-Dizin)” (Doktora Tezi, Frrat Üniversitesi, 1998), 4. Bu doktora tezi daha sonra yayınlanmıştır: Nadir İlhan, Eşref b. Muhammed, Haza 'inu 'sSa'adat: Inceleme, Metin, Sözlük (Malatya: Serhat Yayınları, 2009).

31 Nilüfer Demirsoy ve Ömür Şaylıgil. "Hazâ'inü’s-Sa'âdât’ta Yenidoğan Bakımı Hakkında Bilgiler: XIV-XV. Yüzyıldan Bir Yazma Eser,” Lokman Hekim Dergisi 8, 3 (2018): 240-246. 

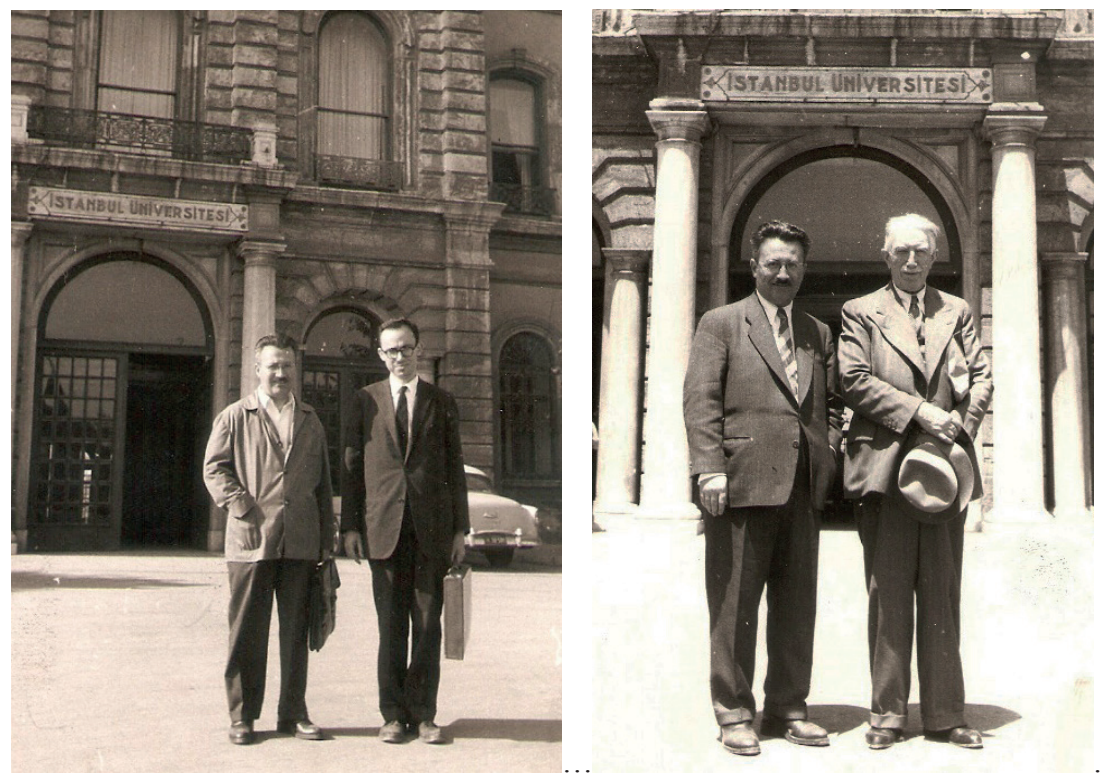

Bedi N. Şehsuvaroğlu, geç dönem Osmanlı tarihi araştırmalarıyla ünlü Prof. Dr. Stanford J. Shaw

(1930-2006) ile 16 Haziran 1955 (solda) (Selami Ahmet Şehsuvaroğlu Arşivi); Türk sanat tarihi araştırmalarının babası kabul edilen arkeolog ve sanat tarihçisi Prof. Dr. Albert Gabriel (1883-1972) ile, 1959 (sağda) (Selami Ahmet Şehsuvaroğlu Arşivi).

Ankara'da 1-5 Mayıs 1957'de toplanan, VIII. Türk Dili Kurultayı'nda, “İlk Türkçe Tıp Yazmalarındaki Tıp Terimleri” hakkında bir bildiri sunmuştur. Türkçe tıp terimlerinin tarihsel gelişimine değinen ilk çalışmadır. ${ }^{32}$ Türkiye Cumhuriyeti'nin 50. yıldönümünde, 15 20 Ekim 1973 tarihlerinde toplanan, I. Milletlerarası Türkoloji Kongresi'ne sunmuş olduğu, “Anadolu'da Türkçeleşme Akımı ve Türkçe İlk Tıp Kitapları” (I. Milletlerarası Türkoloji Kongresi (İstanbul, 15-20 / X / 1973). İstanbul:1979, 507-514) bildirisi, ${ }^{33}$ Eski Anadolu

32 Şehsuvaroğlu, o zamana kadar bilinmeyen bir cerrahnameyi doktora tezi olarak verdiğinde, tıp terminolojisinin çok önemli olduğunu vurgulamış ve eserin sözlüğünü hazırlamamı istemişti. 17 Eylül 1976'da başladığım tezimde metnin Latin harflerine çevirisiyle uğraşırken Bedi Hoca vefat etti. On beşinci yüzyıl tıp terminolojisi hakkında yardım alabileceğim hiç kimse yoktu. Eserde geçen tıp terimlerinin karşılıklarını yine yazma eserlerden bulabilmiş ve kaynaklı bir sözlük hazırlamışıım. Bkz. Nuran Yıldırım, "XV. Yüzyıla Ait Türkçe Bir Cerrahnâme (Doktora Tezi Özeti)," Doktora Tezleri. İstanbul Tıp Fakültesi Mecmuası, 46, Supplementum 90 içinde (İstanbul: İstanbul Tıp Fakültesi, 1983): 227-246; "XV. Yüzyıla Ait Anonim Bir Cerrahnâme Cerrahi Yöntemlerin Kullanıldığı Fasıllar Tibbi Terminoloji ile Bitki, Drog ve Madde İsimleri," Yeni Tip Tarihi Araşttrmalart say1 10-11(2004/2005): 325-433.

33 I. Milletlerarası Türkoloji Kongresi (First International Congress of Turcology) 15-20 / X / 1973 Istanbul. Gündem (Programme). (İstanbul: İstanbul Üniversitesi Edebiyat Fakültesi, 1973), 8, 9. Bu bildirinin ön araştırmasını bana yaptırmıştı. Türkçe yazılmış ilk tıp kitaplarını tespit edip içeriklerini inceleyip hocama vermiştim. Eksikleri tamamlayıp bildiri olarak düzenlemiş, beni de ikinci isim olarak ekleyip düzenleme kuruluna göndermişti. Kongrenin basılı programı geldiğinde, benim adımın çıkarıldığını ve bir oturumda yazmanlık görevi verildiğini görünce çok sinirlenmiş ve düzenleme kurulundan tanıdığı hocalara telefon 
Türkçesi çalışmalarında yeni bir alan açmış ve bu alanda yapılan doktora tezleriyle, 15-16. yüzyıllara ait yazma tıp kitapları birer birer yayınlanmaya başlanmıştır.

Bedi N. Şehsuvaroğlu'nun Niyazi Ahmet Banoğlu ile yayına hazırladığı Zeyneb-Kâmil Hastanesi, 1860-1955 [iç kapakta: Zeyneb-Kamil Hastanesi, 1860-1954] adlı kitap (İstanbul, 1955), bu hastane hakkında yazılmış ilk kitaptır. Daha sonra, Şehsuvaroğlu'nun editörlügünnde yeniden yayınlanmıştır. ${ }^{34}$ Yakın yıllarda yapılan araştırmalarda hastaneye ait dört vakfiye bulunmuş, hastanenin kuruluş tarihinin 2 Mart 1882 olduğu tespit edilmiş ve gelişmesine dair yeni bilgiler eklenmiştir. ${ }^{35}$

Ístanbul'da 500 Yıllık Sağlık Hayatımız (İstanbul, 1953) kitabında, Osmanlı Devleti payitahtında yürütülen sağlık hizmetlerini ve faaliyet gösteren hastanelerle diğer sağlık kurumlarını incelemiş, böylece sonraki kuşaklara şehir sağlık tarihlerini yazma yolunu açmıştır. Yöresel sağlık tarihi yazımına bir örnek de Anadolu'da Dokuz Asırlık Türk Tıp Tarihi'dir (İstanbul, 1957).

İstanbul Tıp Fakültesi Adli Tıp Hocası Prof. Dr. Cahit Özen ile birlikte kaleme aldığı, Dünyada ve Yurdumuzda Adlî Tıbbın Tarihçesi ve Gelişmesi (İstanbul, 1974) adlı yayından başka göz hekimliği, anatomi, patolojik anatomi, dermatoloji, geriatri, kimya, doğum-ebelik tarihleri hakkındaki makaleleriyle tıp branşlarının tarihlerine ve eğitimlerinin gelişmesine ilgi uyandırmıştır. Prof. Dr. Nuran Gökhan ve Prof. Dr. Olcay Neyzi ile birlikte hazırladığı, Cumhuriyetin 50. Yılında İstanbul Tıp Fakültesi (cilt 1, İstanbul, 1974) kitabında da ilk olarak fakülte kürsülerinin tarihçelerini yazmıştır.

Basın Tarihimizde Sıhhî Mevkuteler (İstanbul, 1962), Türkiye'de sağlıkla ilgili süreli yayınlar hakkında yapılmış ilk derlemedir. ${ }^{36}$ Internet arama motorlarının bulunmadığı o dönemde araştırmacıların tıp ve sağlıkla ilgili dergilere ulaşmasını kolaylaştıran bu yayın, daha sonra Türkçe süreli tıp yayınları hakkında yapılan araştırmalara da ilham kaynağı olmuştur.

ederek sebebini sormuş. Türkoloji'deki hocalarım, "Bir iki yıl önce mezun olan bir öğrencimizi uluslararası bir kongreye kabul edemeyiz" demişler. Bedi Bey bildirisini sunacağ 18 Ekim 1973 günü beni de yanına aldı. Edebiyat Fakültesi'ne gittik. Kürsüye davet edildiğinde, oturumu dinlemeye gelen hocalarımın huzurunda, "Bu bildiriyi Osmanlıca okutmanım Nuran İşcan ile birlikte hazırladık. Adının silinmesi ilim ahlakına aykırıdır, bunu yapanlara teessüf ederim. Şimdi bildirimizi sunmak üzere Nuran İșcan'1 kürsüye davet ediyorum" dedi ve kürsüden inip yerine oturdu. O gün sadece bilgi biriktirmekle hoca olunamayacağını öğrenmiştim.

34 A. Süheyl Ünver, Bedi N. Şehsuvaroğlu ve Emine M. Atabek, Zeyneb-Kâmil Hastahanesi, 1860-1960, yay. haz. B. N. Şehsuvaroğlu ([İstanbul]: Kaptanoğlu Matbaası, 1960).

35 Şeref Etker, Feza Günergun ve Abdullah Köşe, “Zeynep-Kamil Hastanesi’nin Kuruluşu ve Vakfiyesi,” Osmanlı Bilimi Araştırmaları 5, 2 (2004): 1-37; Şeref Etker ve Feza Günergun, “Zeynep Kâmil Hastanesi (1875): Romantik Tarihçiliğin Gölgesinden Bir Çıkış Denemesi,” Prof. Dr. Ali Haydar Bayat Anısına Düzenlenen Osmanlı Sağlık Kurumları Sempozyumu - 2 Haziran 2007 içinde, ed. B. Özatalay, N. Yıldırım, M. Çekin (İstanbul: Zeytinburnu Belediyesi, 2008), 147-170.

36 Genişletilmiş baskısı, "Türkiye'de Sağlıkla İlgili Olarak Yayınlanan Periyodikler,” İstanbul Tip Fakültesi Mecmuast 36, 1 (1973): 169-198. 
Yazma eser kütüphanelerinde yaptığı araştırmalar sonunda ulaştığ1, bilinmeyen bir coğrafya kitabını tanıttığı makale, Şehsuvaroğlu'nun bilim tarihimize katkısıdır: “Kanuni Devrinde Yazılmış ve Şimdiye Kadar Bilinmeyen Bir Coğrafya Kitabı" (Kanuni Armă̆anı. Ankara: Türk Tarih Kurumu, 1970). Ayrıca İslâm felsefesini metot, terminoloji ve problemler açısından temellendiren ünlü Türk filozofu Fârâbî ile astronomi, matematik, fizik, tıp, coğrafya, tarih ve dinler tarihi başta olmak üzere çeşitli alanlarda önemli eserler veren, Türk-İslâm ve dünya tarihinin en tanınmış ilim adamlarından Bîrûnî’nin biyografilerini yazmıştır: Fârâbî: 870-950 (İstanbul, 1950), Ebû Reyhan Bîrûnîve Kitâbü 'sSaydele (İstanbul, 1959). Bunlardan başka; Türkiye'de tıp öğretimi, sağlık teşkilatı tarihi, Bergama Asklepionu, Edirne II. Bayezid Dârüşşifası, hastaneler, cüzam, sıtma, frengi, verem, çiçek aşısı, kuduz aşısı, tarihi kolera salgınları, kaplıcalar, akıl hastalıkları tarihi, hekim biyografileri ve benzeri konulardaki yayınları günümüzde de kaynak olarak kullanılmaktadır. ${ }^{37}$

\section{Düzenlediği Kongreler}

Vefatından birkaç ay önce, Münih Tıp Tarihi Kurumu'nun (Münchener Vereinigung für Geschichte der Medizin) işbirliğiyle, Tarihte Türk-Alman Tıbbi İlişkileri Sempozyumu'nu (18-19 Ekim 1976) düzenlemişti. ${ }^{38}$ Sempozyumda, ön araştırmasını o sırada yanında doktora yapmakta olan (ve vefatından sonra Cerrahpaşa Tıp Fakültesi'ne geçen) Ayten Altıntaş'ın yapmış olduğu ve 1933 Üniversite Reformu'nda Türkiye'ye gelen Alman bilim adamlarını konu alan bir sunum yapmıştı. Sempozyumun bildiri kitabını yayınlayamadan vefat edince, basıma hazırlamış olduğu Alman bilim adamlarının biyografileri, Bedi Şehsuvaroğlu'nun yerine atanan anabilim dalı başkanı tarafından kendi adıyla yayınladı. ${ }^{39}$ Şehsuvaroğlu'nun nasibine, kaleme aldığı uzun metinden üç buçuk sayfalık giriş kısmı düşmüştü. ${ }^{40}$

Şehsuvaroğlu, Türkiye'de çağdaş tıp eğitimi uygulamasının 150. yıldönümü münasebetiyle, İstanbul Tıp Fakültesi’nin düzenleyeceği V. Tıp Kurultayı çerçevesinde, I.

37 1948-1970 yılları arasındaki yayınlarını kapsayan iki bibliyografyası yayınlanmıştır: Nazmi Çağan, Dr. Bedii N Şehsuvaroğlu Biyografi ve Bibliyografyası (1948-1960) (İstanbul: İstanbul Üniversitesi Tıp Tarihi Enstitüsü Yayın No. 59, 1963); Nazmi Çağan, Bedi N. Şehsuvaroğlu Biyografi ve Bibliyografyası II (19471970) (İstanbul: İstanbul Şehir Kütüphanesi Kurma ve Yaşatma Derneği, 1973). 1977 sonrası yayınları için bkz. Aykut Kazancigil, ve Vural Solok, Türk Bilim Tarihi Bibliyografyası (1850-1981) (İstanbul: İstanbul Üniversitesi Cerrahpaşa Tıp Fakültesi, 1981).

38 Bedi N. Şehsuvaroğlu, "Tarihte Türk-Alman Tıbbi İlişkileri,” İstanbul Tıp Fakültesi Mecmuası 40, 3 (1977): 720-737.

39 Arslan Terzioğlu, "Türkiye'de Görev Yapmış Olan Alman Asıllı Tıp ve Deneysel Bilim Dallarındaki Profesörlerin Biyografileri (Alfabetik)," Türk-Alman Tıbbî Ilişskileri. Simpozyum Bildirileri 18-19 Ekim 1976, İstanbul içinde, yay. haz. Arslan Terzioğlu (İstanbul: İstanbul Üniversitesi İstanbul Tıp Fakültesi, 1981), 131216.

40 Bedi N. Şehsuvaroğlu, "Anadolu Türk Tıbbının Batılılaşmasında Alman Hekimlerin XIX. Yüzyıl Başlarından Beri Süregelen Etkileri,” Türk-Alman Tıbbî İlişkileri. Simpozyum Bildirileri 18-19 Ekim 1976, İstanbul içinde, yay. haz. Arslan Terzioğlu (İstanbul: İstanbul Üniversitesi İstanbul Tıp Fakültesi, 1981), 17-21. 
Deontoloji Kongresi'nin de yer almasını önermiş, teklifi kabul edilmişti. Hemen çalışmalarına başlayarak tıp ve hukuk alanlarından ilgililerle temasa geçip bildiri özetlerini toparlamış ve kongre programını hazırlayıp dosyalamıştı. Âniden vefat edince, Tıp Fakültesi Dekanı Prof. Dr. Güngör Ertem, kürsüye gelerek kongre hazırlıklarının hangi aşamada kaldığını sordu. Kongre dosyasını gördüğünde çok memnun oldu ve kongrenin düzenlenmesine karar verdi. Şehsuvaroğlu'nun yaptı̆̆ı hazırlıkla I. Türk Tıbbi Deontoloji Kongresi, onun vefatından sonra, 25-30 Eylül 1977 tarihlerinde, düzenleyenler arasında bu satırların yazarının da bulunduğu bir ekip tarafından gerçekleştirildi. Kongreye sunulan bildirilerin özetleri Türkçe ve İngilizce olarak iki ayrı kitapçıkta basıldı. ${ }^{41}$ Bildiri kitapçı̆̆ının önsözünde Tıp Tarihi ve Deontoloji Kürsüsü başkanlığını vekâleten yürütmekte olan Prof. Dr. Cahit Özen, kongrenin önemini şu sözlerle dile getirmişti:

Günümüzde medikal deontoloji çok çeşitli konuları kapsamaktadır. Bu konuların bilimsel temeller içinde öğrenilmesi ve uygulanması hekimi bilgili, etik ve vicdanlı bir insan olarak hekimlik pratiğine hazırlar. Hekimin bu yolda uyacağı deontoloji prensipleri ise insan hayatını ve sağlığını korumak acıları dindirmektir. I. Medikal Deontoloji Kongresinde bütün bu konuların tıp ve hukuk açısından ele alınarak incelenmesi ve bazı sonuçlara varılması hedef olarak alınmıştır. Hipokrat’tan önceki kişisel tıp bugün hekimlerin mesleki görevleri, adlî görevleri, tıp hukuku, toplum hekimliği ve sosyal tıp gibi değişik yönler alırken medikal deontolojide de ilaç alışkanlığı, organ nakli, doğum kontrolü, sun’i döllenme ve euthanasie gibi yeni konularda en insancıl tutumun saptanması medikal deontolojinin içine girmiştir. Nitekim kongrede bu konular ele alınarak bazı sonuçlara varılmakta, hekim sorumluluğunun tıp ve hukuk açısından önemi ve ortaya koyacağı problemler incelenmektedir.

Kongrede ele alınan konulara bakıldığında, henüz etik sözcüğünün gündemde olmadığ1 o yıllarda; yapay döllenme, organ nakli sorunları, gönüllüler üzerinde ilaç araştırması, hayatın başı ve sonu gibi günümüzde tıp etiği kapsamına giren konuların da irdelendiği görülecektir:

- Tibbi Deontolojide “Ortak Sorumluluk” Sorunu (Dr. Erdoğan Acarlar)

- Türk Tıbbının Laikleşmesi ve Deontoloji (Doç. Dr. Sırrı Akıncı)

- Eczacilık Deontolojisinin Medikal Deontoloji İçindeki Yeri ve Yasal Sorunlar (Ecz. Dr. Eriş Asil)

- Sun'i İlkah İle İlgili Deontoloji Problemleri (Doç. Dr. Emine M. Atabek)

- Tıbbi Deontoloji (Dr. Erdal Atabek, Türk Tabipler Birliği Başkanı)

- İslâma Göre Doğum Kontrolü, Organ Nakli ve Sun'i Döllenme (Dr. Ali Arslan Aydın, Diyanet İşleri Başkanlığı Din İşleri Yüksek Kurulu Üyesi)

- Bir Özel Hukuk Sorunu Olarak Organ Nakli (Prof. Dr. Nuşin Ayiter, Ankara Üniversitesi Hukuk Fakültesi)

- Değişik Örnekleri ve Deontolojik Kurallarıyla Yemin (Prof. Dr. Zeki Başar)

41 Istanbul Tıp Kurultayl 25-30 Eylül 1977. I. Türk Tıbbi Deontoloji Kongresi Bildiri Özetleri. Istanbul Medical Convention 25-30 September 1977. 1st Congress On Medical Deontology Abstracts of Communications (İstanbul: Sermet Matbaas1, 1977). 
- Yugoslavya'da Aile Planlamasının Deontolojik ve Mediko-Legal Yönleri (Prof. Dr. Berislav Beric, Novi Sad Üiversitesi Tip Fakültesi; Prof. Dr. Dr. Milos Stevanov, Novi Sad Üniversitesi Hukuk Fakültesi)

- Hekimlik ve Hukuk Bakımından Hayatın Başı ve Sonu (Asis. Dr. Ayşegül Demirhan)

- Hekimlik Sır Saklama Yükümlülüğü (Doç. Dr. Süheyl Donay, İstanbul Üniversitesi Hukuk Fakültesi)

- Tip Deontolojisi ve Hukuk ve Ceza Sorumluluğu (Ord. Prof. Dr. Sulhi Dönmezer, İstanbul Üniversitesi Hukuk Fakültesi)

- Oral Gebelik Önleyicilerin Günümüzdeki Uygulamaları ve Yan Etkileri (Doç. Dr. Yalçın Eğeci, İ.Ü. İstanbul Tıp Fakültesi)

- Hekim-Reçete-Eczacı Bağlantısında Medikal Deontolojik Sorunlar (Doç. Dr. Şükran Geçgil, İstanbul Üniversitesi Eczacılık Fakültesi)

- Tıbbi Deontoloji ve Yarını (Dt. Tonguç Görker, Türk Diş Hekimleri Birliği Başkanı)

- Tarihi Perspektifte Deontoloji ve Bugüne İlişkin Görüşler (Dr. İbrahim Gürol, Sağlık ve Sosyal Yardım Bakanlığı Danışma ve İnceleme Kurulu Başkanı)

- Esrar Kullanılması Serbest Bırakılabilir mi? (Prof. Dr. Şükrü Kaymakçalan, Ankara Üniversitesi Tıp Fakültesi)

- Tıp Biliminde Ortaya Çıkan Gelişmelerin Toplum ve Kişi Açısından Hukuksal Niteliği (Asis. Dr. Tennur Koyuncuoğlu, İstanbul Üniversitesi Hukuk Fakültesi)

- Askeri Tababette Deontoloji (Dr. Hulki Müderrisler, Haydarpaşa Askeri Hastanesi Başhekimi)

- Anesteziyolojist-Cerrah İlişkileri-Karşılıklı Sorumluluklar (Prof. Dr. Faruk Or, İ.Ü. İstanbul Tıp Fakültesi)

- Tibbi Psikoloji ve Deontolojik Sorunlar (Yılmaz Özakpınar, İstanbul Üniversitesi Edebiyat Fakültesi Tecrübi Psikoloji)

- Deontoloji ve Adli Tıp Yönünden Tıbbi Raporlar (Prof. Dr. Cahit Özen, İ.Ü. İstanbul Tıp Fakültesi)

- Dermatolojide Deontolojik Sorunlar (Doç. Dr. Türkân Saylan, İ.Ü. İstanbul Tip Fakültesi)

- Deontolojik Sorunlar (Prof. Dr. Bedi Şehsuvaroğlu, İstanbul Tıp Fakültesi)

- Gönüllüler Üzerinde İlaç Araştırması ve Türkiye'nin Durumu (Doç. Dr. Cankat Tulunay, Ankara Üniversitesi Tıp Fakültesi)

- Transplantasyonlar ve Sorunları (Prof. Dr. Alaettin Vardar ve Dr. Tuncay Turfanda, İ.Ü. İstanbul Tıp Fakültesi)

- Ceza Hukuku Karşısında Hekimin Sorumluluğu (Doç. Dr. Köksal Bayraktar) ${ }^{42}$

\section{Şehsuvaroğlu'nun Üyesi Olduğu Bilimsel Dernekler}

Türk Tıp Tarihi Kurumu (2. Başkan); Türk Sosyoloji Cemiyeti; Türk Fizikî ve Tabiî İlimler Cemiyeti; National Geographic Society (asil üye); Société internationale d'Histoire de la Médecine (asil üye); L'Académie internationale d'Histoire des Sciences (asil üye); L'Académie de la Méditerranée (muhabir üye).

42 Basıma yetiştirilemeyen bu bildirinin özeti teksir makinesiyle çoğaltılarak bildiri kitapçığının arasına eklenmiştir. 


\section{Şehsuvaroğlu'nun Tıp Tarihi Müzeciliği}

1933 Üniversite Reformu ile İstanbul Darülfünunu yeniden yapılandırılarak İstanbul Üniversitesi’ne dönüştü. Bu sırada yeni kurulmuş olan Tıp Tarihi Enstitüsü’ne İstanbul Üniversitesi'nin Beyazıt'taki Merkez Binasının (bugün Rektörlük binası) ikinci katında küçük bir oda verilmiş başına da Dr. A. Süheyl Ünver tayin edilmişti. İlk yapılanma döneminde Tıp Fakültesi Dekanlığg, fakülte kütüphanesindeki yazma eserler ile Arap harfli matbu tıp kitaplarını, eski mühürlerle resimleri enstitüye göndermişti. Tıp Fakültesi Kütüphanesi’nden gelenler arasında, Bartholomei Eustachii (1521-1574)'nin Tabulae Anatomicae (Roma, 1728) adlı eseri, 1827 'de kurulmuş olan Tıphane-i Âmire'nin mührünü ve Mekteb-i Tıbbiye-i Şahane'nin mührünü taşıyan kitaplar vardı. Tıp Fakültesi'nde ilk radyografilerin çekiminde kullanılan Crookes tüpü de bu dönemde müzeye kazandırılmıştı. A. Süheyl Ünver toplamış olduğu çeşitli malzemeyi de eklemek suretiyle tıp tarihi müzesinin temelini atmıştır.

Cumhuriyet gazetesine, “İstanbul Üniversitesi Tıp Tarihi Enstitüsünden” başlı̆gı ile verilen bir ilanda; Türk tıp tarihine ait mühim bir kütüphane ve müze kurulmakta olduğu, bu müzede eski ve yeni hekimler ile ailelerinin evlerinde kalmış resim, diploma, aletler ve eserlerinin teşhir olunacağı vurgulanmış ve bu gibi yâdigârı olup da vermek isteyenlerin bir mektupla bildirmeleri yahut göndermeleri rica edilmişti. ${ }^{43} \mathrm{O}$ yıllarda müze ve koleksiyon ayrımı yapılmadığından, toplanmakta olan objeler, tablolar ve belgeler, Tıp Tarihi Müzesi olarak adlandırılmış ve demirbaş kayıtları da bu şekilde tutulmuş. Şehsuvaroğlu Tıp Tarihi Enstitüsü'nde asistan olarak göreve başladıktan sonra çeşitli şehirlere yaptığı araştırma gezilerinde topladığı folklorik malzemeyle müzeyi zenginleştirmişti.

1948 yılında vefat eden Prof. Dr. Neş’et Ömer İrdelp'in kütüphanesi ve ertesi sene hayata veda eden Prof. Dr. Âkil Muhtar Özden'in ve daha sonra vefat eden Prof. Dr. Tevfik Salim Sağlam'ın kütüphanesi ile evrakı Tıp Tarihi Enstitüsü’ne bağışlandı. Bu kütüphanelerin her biri orijinal dolaplarında ayrı ayrı odalara yerleştirildi. Şehsuvaroğlu, kürsüye intikal eden iki kitaplığın bibliyografyasını hazırlamıştır: Doktor Akil Muhtar Özden Bibliyografyası (İstanbul, 1951) ve Ord. Prof. Dr. Tevfik Salim Sağlam Kütüphanesi Kataloğu (Leman Bakla ile, İstanbul, 1970).

Kütüphanesi yanında Tevfik Salim Sağlam'ın masası, altın kaplama yazı takımı ve ahşap oymacılığının en güzel örneklerinden sayılan sandalyesi, evrakı arasında bulunan fotoğraflar, I. Dünya Savaşı'nda III. Ordu Sıhhiye Reisliği (Erzurum) yaparken hazırladığı raporlar, hem orduda hem de çevre şehirlerde başta tifüs olmak üzere salgın hastalıklarla yürüttüğü mücadele çalışmalarının raporları ve krokileri de Tıp Tarihi Enstitüsü’nün malı olmuştu.

Aynı zamanda bir ressam olan Âkil Muhtar Özden'in yaptığı pek çok suluboya resim, seyahat ettiği yabancı ülke şehirlerinin tarihini, mimarisini ve ünlü bilim insanlarını resmettiği defterler, kimlikleri, madalyaları, preparat koleksiyonu, fotoğrafları ve fotoğraf albümleri ile

43 “İstanbul Üniversitesi Tıp Tarihi Enstitüsünden,” Cumhuriyet, 28 Kasım 1935. 
kullandığı kardiyografi cihazı gibi değerli objeler, ayrıca ünlü Ressam Feyhaman'ın (Duran) eseri olan Âkil Muhtar Özden ile aile bireylerinin yağlıboya tabloları, kızı Aliye Haldun Sarhan tarafından Tıp Tarihi Müzesi’ne bağışlanmıştı.

Âkil Muhtar Özden, II. Abdülhamid ile Atatürk'ün müdavi hekimlerindendi ve ölümlerine tanık olmuştu. Bu iki devlet adamını ölüm döşeklerinde gösteren karakalem çizimleri, Atatürk'ün son hastalığı sırasında tuttuğu günlük mahiyetindeki notları Tıp Tarihi Müzesine intikal etmiştir. Şehsuvaroğlu, Âkil Muhtar Özden'in Atatürk'ün son hastalığında tuttuğu notları yayına hazırlamıştı. Onun ani vefatı üzerine ailesi tarafindan, Atatürk'ün Sağllk Hayatı. Atatürk'ün Doğumunun 100. Yılı 1881-1981 (İstanbul: Hür Yayın Tarih Dizisi, 1981) adıyla yayımlandı.

Atatürk'ün son hastalığında üçüncü karın ponksiyonunu yapan, müdavi hekimlerinden Dr. Mehmet Kâmil Berk, bu işlem sırasında kullandığ 1 trokarı ve son koma esnasında zerk edilen serum glikoze tüpünü, Prof. Dr. A. Süheyl Ünver'in isteği üzerine, Atatürk'ün hastalığını anlattığı 20 Mayıs 1956 tarihli mektupla birlikte, Tıp Tarihi Müzesi'ne hediye etmiştir. ${ }^{44}$ Müzede ayrıca Atatürk'ün saçından birkaç tel ile sigara tabakası bulunmaktadır.

Şehsuvaroğlu sık sık İstanbul Tıp Fakültesi kliniklerine gider, varsa kullanım dışı mikroskopları, tıbbi ve cerrahi aletleri, protezleri aldırıp kürsüye getirtirdi. Ayrıca emekli hocaları evlerinde ziyaret edip şahsi evrakını müzeye bağışlaması için ikna ederdi. $\mathrm{Bu}$ ziyaretlerinden diplomalar ve resimlerle döndüğünde çok mutlu olurdu. Resmi kurumlara giderek yetkililerle görüşür, sağlık tarihi mirasının önemini vurgular, tarihi öneme sahip malzemenin müzeye bağışlanmasını sağlardı. Bu girişimlerle müzeye intikal eden, Tıp Fakültesi Eczacı Mektebi talebe dosyaları (974 adet) ile harem ağalarına ait defterler (43 adet), tarihe 1 şık tutacak kazanımlardır.

Bedi Şehsuvaroğlu, Avrupa'daki meslektaşlarının çoğu ile dostluk kurmuştu. Roma Üniversitesi’ndeki Tıp Tarihi Kütüphanesi (1938) ile Tıp Tarihi Müzesi’ni (1954) kurmuş olan Tıp Tarihi Enstitüsü Başkanı Prof. Dr. Adalberto Pazzini (1898-1975) de dostları arasındaydı. Daveti üzerine İstanbul'a gelen Pazzini’ye geliştirmekte olduğu Tıp Tarihi Müzesi’ni gezdirmiş ve katkıda bulunmasını rica etmişti. Pazzini İtalya’ya dönünce Tıp Tarihi Müzesi için, pişmiş topraktan fallos heykelciği, ${ }^{45}$ toprakaltından çıkmış spekulum ve diğer bazı cerrahi aletler göndermişti (1969). ${ }^{46}$

44 Asuman Baytop, "Bir Hastane Hekimi Dr. M. Kâmil Berk (1878-1958), Mesleki Faaliyeti ve Bilimsel Yayınları," erişim 16 Haziran 2018, http://www.bilimtarihi.org/pdfs/mehmet_kamil.pdf; Arslan Terzioğlu, “Atatürk'ün Son Hastalığı ve Tedavisinde Kullanılan Tıbbî Aletler,” Bifaskop 4, 2 (Nisan 1981): 2-8.

45 Aralık ayında kutlanan İkinci Dionysos Bayramına (Küçük Dionysia) katılanlar pişmiş topraktan erkeklik organı şeklinde yapılmış fallos heykelcikleri taşıyarak kırlık alanlara gider, burada türküler ve şiirler söyler, düzenledikleri oyunların ardından ektikleri tohumun bereketli olacağına inanırlardı. Bkz. Çağatay Yücel, “Dionysos Bayramları ve Şenlikleri," Sosyal Bilimler Enstitüsü Dergisi 4 (2015): 151-164.

46 Gönül Güreşsever Cantay, "İstanbul Tıp Fakültesi Tıp Tarihi Müzesi Anılarım,” Sağllk Tarihi ve Müzeciliği Sempozyumu 3, 19-21 Mayıs 2017 içinde, ed. Semih Atış ve Murat D. Çekin (İstanbul: Zeytinburnu Belediyesi Kültür Yayınları, 2018), 163-170. 


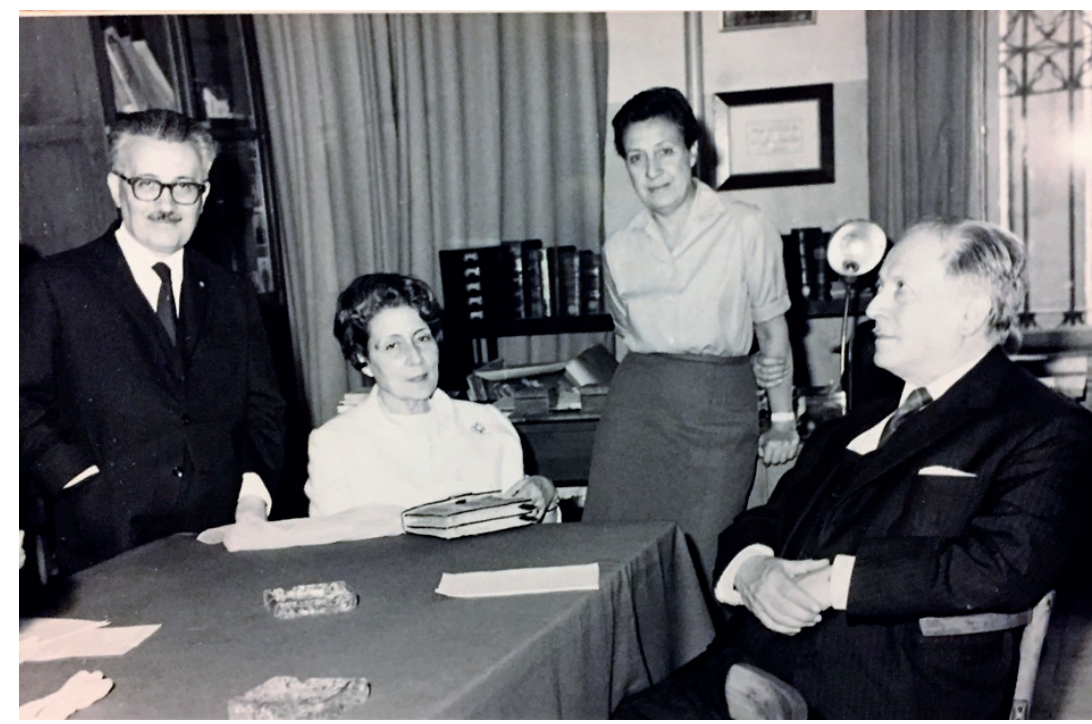

Prof. Dr. Bedi N. Şehsuvaroğlu (solda), İtalyan tıp tarihçisi Prof. Dr. Adalberto Pazzini (1898-1975) (sağda), eşi ile Tıp Tarihi Enstitüsü'nün seminer salonunda. Ayakta duran hanım, Dr. Emine Melek Atabek’tir (1914-2000) (Selami Ahmet Şehsuvaroğlu Arşivi).

Kırım Savaşı sırasında gelip savaştan sonra İstanbul'da kalan yabancı hekimlerin 1856'da kurmuş olduğu Cemiyet-i Tıbbiye-i Şahane'nin mührünü taşıyan tıp kitaplarının, 1970’lerin başında Şehsuvaroğlu'nun girişimiyle Tıp Tarihi Kürsüsü’ne dahil edildiğine tanık oldum. Kamyonla gelen ve yer bulunamadığı için depoya kaldırılan bu kitaplar 2011'de kayıt altına alındı.

A. Süheyl Ünver ile Şehsuvaroğlu'nun ortak çabalarıyla zenginleşen yazma eser kitaplığı, birkaç eser dışında Ünver tarafından Cerrahpaşa Tıp Fakültesi’ne götürülmüştür (1970). Bundan sonra Şehsuvaroğlu, sahaflarla kurduğu iyi ilişkiler sayesinde birçok eser satın alarak yeni bir yazma eser kitaplığı oluşturmuştur. 1465 yılında ünlü Osmanlı hekim ve cerrahı Şerefeddin Sabuncuoğlu tarafından yazılmış olan Cerrâhiyye-i İlhâniyye'nin bilinen üç nüshasından biri müzededir. Cerrahi hastalıklar ile ameliyatların anlatıldığı bu eser, minyatür tekniği ile çizilmiş resimleri bakımından çok önemlidir. ${ }^{47}$ Eczacılık tarihimize önemli katkılar yapmış olan Ecz. Naşid Baylav'ın (1903-1982) kitaplığında bulunan, Sabuncuoğlu'nun kişisel deneylerini anlattı̆̆ı, Mücerrebnâme eserinin bir nüshası vefatından sonra Baylav ailesinden satın alınmıştır.

47 Hakkında yapılan ayrıntılı bir inceleme için bkz. Yıldırım, Nuran. "Cerrâhiyye-i İlhâniyye, Şerefeddin Sabuncuoğlu'nun Gözlem ve Deneyimleri, Cerrahi Yöntemler ve Ameliyatlar,’ Journal of Turkish Studies/ Türklük Bilgisi Araştırmalarl 47 (2017), eds. Cemal Kafadar and Gönül Alpay Tekin - Festschrift in Honor of the Millet Library's 100th Year and its Founder Alî Emîrî Efendi. Part II, guest eds. Günay Kut and Bedri Mermutlu (Cambridge, MA: Harvard University, 2017), 297-347. 
1970’li yıllarda Çapa'da, günümüzde İstanbul Tıp Fakültesi Dekanlığı'nın bulunduğu binanın planları hazırlanmaktaydı. Şehsuvaroğlu'nun çabalarıyla giriş katı Tıp Tarihi Müzesi'ne ayrılmış ve planı Bedi Bey’e gönderilmişti. Şehsuvaroğlu'nun vefatından sonra giriş katının başka amaçlarla kullanılacağını duyunca, planın kürsüde bulunan kopyasını dönemin dekanına ve yardımcılarına götürüp gösterdiysem de bir yararı olmadı. Plan değiştirilmiş, giriş katı başka birimlere tahsis edilmişti.

1983 ’te yürürlüğe giren 2863 sayılı Kültür ve Tabiat Varlıklarını Koruma Kanunu'nun 26. maddesi bakanlıklara, kamu kurum ve kuruluşlara, gerçek ve tüzel kişiler ile vakıflara, Kültür ve Turizm Bakanlığı'ndan izin almak şartıyla, kendi hizmet konularını veya amaçlarını gerçekleştirmeleri için, her çeşit taşınır kültür varlığını içeren özel müzeler kurma yetkisini vermiştir. Bu kanun ve yönetmelik yürürlüğe girdikten sonra, bu kanunla belirlenen kriterler yerine getirilmeyince Tıp Tarihi Müzesi, müze olmaktan çıkıp koleksiyon kapsamına girmiştir.

1983-2011 yılları arasında Fatih’teki Abdüllatif Suphi Paşa Konağı'nda hizmet veren Tıp Tarihi ve Etik Anabilim Dalı, İstanbul Tıp Fakültesi Çapa yerleşkesine taşınırken; yazma eserler, basma Arap harfli Türkçe tıp kitaplarından önemli olanlar, tarihi önemi haiz fotoğraf albümleri, radyografi albümleri, preparat koleksiyonları ile eski fotoğrafların çoğu sayısallaştırılmış, “İstanbul Tıp Fakültesi Tıp Tarihi Müzesi” adıyla kayda geçirilip depoya kaldırılmıştır (2011). Uygun bina bulunmadığı için bunlar sergilenememektedir. ${ }^{48}$

Şehsuvaroğlu, Türkiye'nin ilk sağlık tarihi müzesi olan İstanbul Tıp Fakültesi Tıp Tarihi Müzesi’ne yaptığı katkılarla sağlık tarihi mirasımızı gelecek kuşaklara aktarmış ve tıp tarihi araştırmalarına önemli bir kaynak kazandırmıştır.

\section{Bedi N. Şehsuvaroğlu Arşivi}

Bilgiye önem veren Şehsuvaroğlu'nun bir merakı vard1. Tıp tarihi yanında bütün tarihi olaylar, kişiler ve mekânlar ile ilgilenirdi. Akla gelebilecek her şey hakkında bilgi, belge fotoğraf biriktirir, her şey kayboluyor telaşı içinde devamlı toplardı. Arşivlediği malzemenin uygun bir yerine kaşesini basar, âdeta ölüme meydan okurdu.

Her gün çantasında üç dört gazete ile gelirdi. Önce gazeteleri okur; üniversiteler ile ilgili haberleri, hocalarla ilgili haberleri, tanınmış kişilerin veya hocaların ölüm ilanlarını keser, üstüne tarih atar, gazetenin adını yazardı. Bu kupürler arşivdeki dosyalarına yerleştirilirdi. Şubat ayında sömestr tatili boyunca arşiv dosyalarının içindekileri saydırır, o yıl dosyada kaç belge, kaç resim, kaç gazete kupürü bulunduğunu iç kapağına yazdırırdı. Bu arşiv dosyalarında akla gelen her konuda bilgi ve orijinal belgeler bulmak mümkündür.

48 Nuran Yıldırım ve Hakan Ertin, "İstanbul Tıp Fakültesi Tıp Tarihi Müzesi/Koleksiyonu, 1933-2015,” Sağlık Tarihi Müzeciliği Sempozyumu 1, 24 Mayıs 2015, ed. Fatma M. Şen ve Murat D. Çekin içinde (İstanbul: Zeytinburnu Belediyesi Kültür Yayınları, 2016), 39-53. 
Tanıdığg biri veya ünlü bir hekim vefat edince hemen evine gider ve ne yapar eder ailesini ikna edip evrakını alırdı. Diplomaları müzeye, resimleri ve belgeleri arşive kaldırır, kitapları da kürsü kitaplığına kaydettirirdi.

Arşiv dosyaları konularına göre dolaplara yerleştirilmişti. "Umumi” dolabında; pehlivanlar, güzellik yarışmaları, kahve, sigara, çiçekler, bahçecilik, ayakkabıcılık, moda, saçsakal gibi konularda dosyalar vardı. "Tarih" dolabındaki dosyalar belge bakımından zengindi. Araştırma yapan tarihçiler sık sık gelip kullanırdı. "Lexicon” dolabında gelmiş geçmiş ve o sıralarda görevde olan bütün tıp hocalarının dosyaları bulunurdu. Bedi hoca eğitime önem verirdi. Bu nedenle eğitimin her kademesiyle ilgili zengin bir arşivi vardı. "Eczacılık Tarihi" dolabında; ünlü eczacılar, ilaç firmaları, tıbbi bitkiler, ilaçlar, ilaç prospektüsleri bulunurdu.

Küçük yaşlarından itibaren toplamaya başladığı ve özel gayretleriyle zenginleştirdiği arşivinden pek çok araştırmacı, yükssek lisans ve doktora öğrencisi yararlanmıştır. Türkiye Cumhuriyeti'nin 50. Yılı nedeniyle tasarlanan İstanbul 1973 Il Ylllı̆̆ ’’nın hazırlık komisyonu başkanlığına getirilen Şehsuvaroğlu, arşivini açarak bu eserin hazırlanmasına büyük katkıda bulunmuştur.

Tıp Tarihi ve Etik Anabilim Dalı, İstanbul Tıp Fakültesi Çapa yerleşkesine taşınırken 5. 920 dosya, "Bedi N. Şehsuvaroğlu Arşivi” adıyla kayıt altına alındı (2011). Arşiv, yersizlik nedeniyle kullanıma kapalıdır. ${ }^{49}$

\section{Öğrencileri}

Bilim insanlarının eserleri kadar, izini sürecek akademisyenler yetiştirmesinin önemini sık sık dile getiren Şehsuvaroğlu, tıbbın çok disiplinli bir alan olduğunu söylerdi. Bu nedenle kürsüsüne; eczacılık, diş hekimliği, sanat tarihi, türkoloji gibi değişik branşlardan elemanlar almış ve onlara doktora yapma firsatı vermiştir (o zamanlar yüksek lisans yoktu). Her birinin eğitim almış olduğu alanlarla ilgili Türk Tıp Tarihi konularını araştırmalarını isterdi. Kürsü çalışanlarından Gönül Güreşsever (Cantay), İ.Ü. Edebiyat Fakültesi Sanat Tarihi Bölümü'nde doktora yapıyordu. Bedi Bey kendisine, Osmanlı menzil kervansarayları konulu tezinin saha araştırmalarını yapmak üzere Anadolu'nun muhtelif şehirlerine gitmesi için özel izinler verirdi. ${ }^{50}$ Tek şartı gittiği yerlerde tıp tarihi ile ilgili yapıların fotoğraflarını çekmesi ve folklorik tıp ile ilgili objeler getirmesiydi. Anadolu'da sürdürdügü bu seyahatlerde yakından inceleme olanağı bulduğu Anadolu darüşşifaları Cantay’ın doçentlik tezinin konusu olmuştur

49 Hakan Ertin ve Ceren İlikan Rasimoğlu, "Nuran Yıldırım ile Tıp Tarihi Kariyeri Üzerine," Nuran Yıldirım Armağan Kitabı Tip Tarihinin Peşinde Bir Ömür içinde, ed. Hakan Ertin ve M. İnanç Özekmekçi (İstanbul: BETİ, 2016), 23-24.

50 Gönül Güreşsever Cantay, “Anadolu Türk Mimarisinde Darüşşifalar (Hastahaneler)'ın Gelişmesi” (Doçentlik Tezi, İstanbul Üniversitesi, 1982); Gönül Güreşsever Cantay, Osmanlı Menzil Kervansarayları (İstanbul: Fatih Sultan Mehmed Üniversitesi, 2016). 
(Anadolu Türk Mimarisinde Darüşşifalar (Hastahaneler)'ın Gelişmesi, Doçentlik Tezi, 1982, İstanbul Üniversitesi Edebiyat Fakültesi Arkeoloji ve Sanat Tarihi Bölümü Prehistorya Anabilim Dalı). Gönül Güreşsever (Cantay), sonraları akademik kariyerini sanat tarihi alanında sürdürerek profesörlüğe yükseldi.

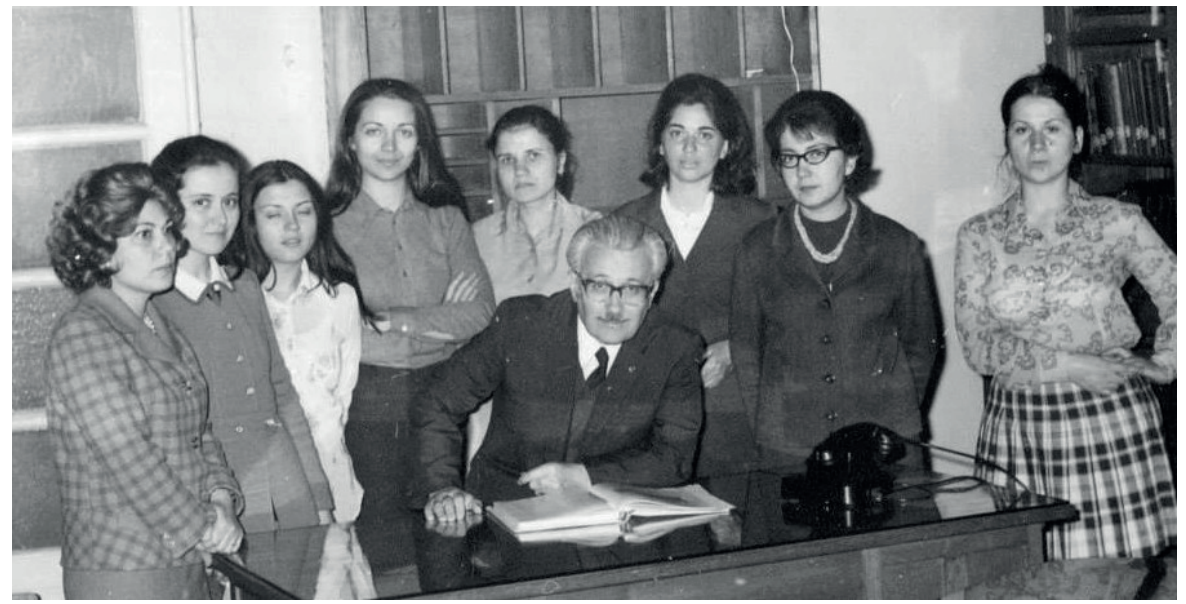

Prof. Dr. Bedi N. Şehsuvaroğlu çalışma arkadaşlarıyla. Soldan sağa; Kâmuran Topuz, Ayşegül Demirhan, Melek Gürel, Nuran İşcan Yıldırım, Servet Küçük, Gönül Güreşsever Cantay, Dilek Kurtoğlu, Songül. İstanbul Üniversitesi Merkez Bina, Tıp Tarihi Enstitüsü seminer salonu. Mayıs, 1973 (Nuran Yıldırım Arşivi).

Şehsuvaroğlu, doktora öğrencilerinden eğitimlerini yarıda bırakıp meslek hayatına atılan olduğunda çok üzülürdü. O yıllarda İstanbul Tıp Fakültesi’nde tıp, eczacılık ve diş hekimliği fakülteleri mezunları doktora yapardı. Diğer fakülteleri bitirenler kabul edilmezdi. Şehsuvaroğlu Osmanlıca Okutmanı olarak kürsüsüne aldığı, Edebiyat Fakültesi Türk Dili ve Edebiyatı mezunu Nuran İşcan'ın (Yıldırım) Tıp Fakültesi'nde doktora yapması için Profesörler Kurulu üyelerini ikna etmiş ve doktora çalışmalarına başlamasını sağlamıştı (1976).

Prof. Dr. Ayşegül Demirhan Erdemir (1974) dışındaki doktora öğrencileri; Prof. Dr. İlter Uzel (1979), Prof. Dr. Ayten Altıntaş (1982; Şehsuvaroğlu'nun vefatından sonra Cerrahpaşa Tıp Fakültesi'ne geçmiştir), Prof. Dr. Nuran Yıldırım (1982), Prof. Dr. Öztan Usmanbaş (1982) ve Dr. Cevat Yalın (1983) tezlerini vefatından sonra tamamlamışlardır.

\section{Kültürle İlgili Çalışmaları}

Şehsuvaroğlu, eğitim ve bilimsel faaliyetleri yanında kültürün her alanıyla ilgiliydi. Tarih, sanat tarihi, edebiyat, resim, müzik, kütüphanecilik, mimarlık gibi kültür ve sanat alanlarında ün kazanmış dostları vardı. Onlarla 1946 yılında evinde haftalık bilim ve kültür 
toplantıları yapmaya başlamıştı. Üniversite'ye intisap edince bu toplantıları 1952'den itibaren çalışma odasında, 1970’ten sonra da seminer salonunda ölünceye dek sürdürdü. Perşembe günleri yapıldığ 1 için "Perşembe Toplantıları" adıyla anılan bu toplantılarda her hafta dönemin tanınmış bir bilim ya da kültür insanı sunum yapar, konu etrafında sorucevap şeklinde sohbet edilirdi. Her toplantı kürsü fotoğrafçısı tarafindan fotoğraflanır ve arşivlenirdi.

Bu toplantılara ünlü ressamlardan Ali Sami Boyar, Feyhaman Duran, Avni Lifij ve Celal Esat Arseven gelirdi. Feyhaman Duran'ın eşi Güzin Duran ile Avni Lifij'in eşi Harika Lifij, Topkapı Müzesi Müdürü Tahsin Öz, Mevlânâ ahfadından müzisyen şair rebabzen Sabahattin Volkan, Ecz. Halil Can, nümizmat İbrahim-Cevriye Artuk çifti toplantıların müdavimleriydi. Emekli generaller Fahri Belen, Nazmi Çağan, Müslim Gür ve Kemal Özbay $^{51}$ her toplantıya gelip hararetli tartışmalara katılırlardı. Şehsuvaroğlu kürsü çalışanlarını bu toplantılara girmeye mecbur tutardı. Toplantının ertesi günü, "Ne öğrendin anlat bakalım?" sorusu karşısında mahcup olmamak için herkes konuşmacıyı dikkatle dinlerdi. Şehsuvaroğlu'nun vefatından sonra o çevre dağıldı ve toplantılar da yapılmaz oldu.

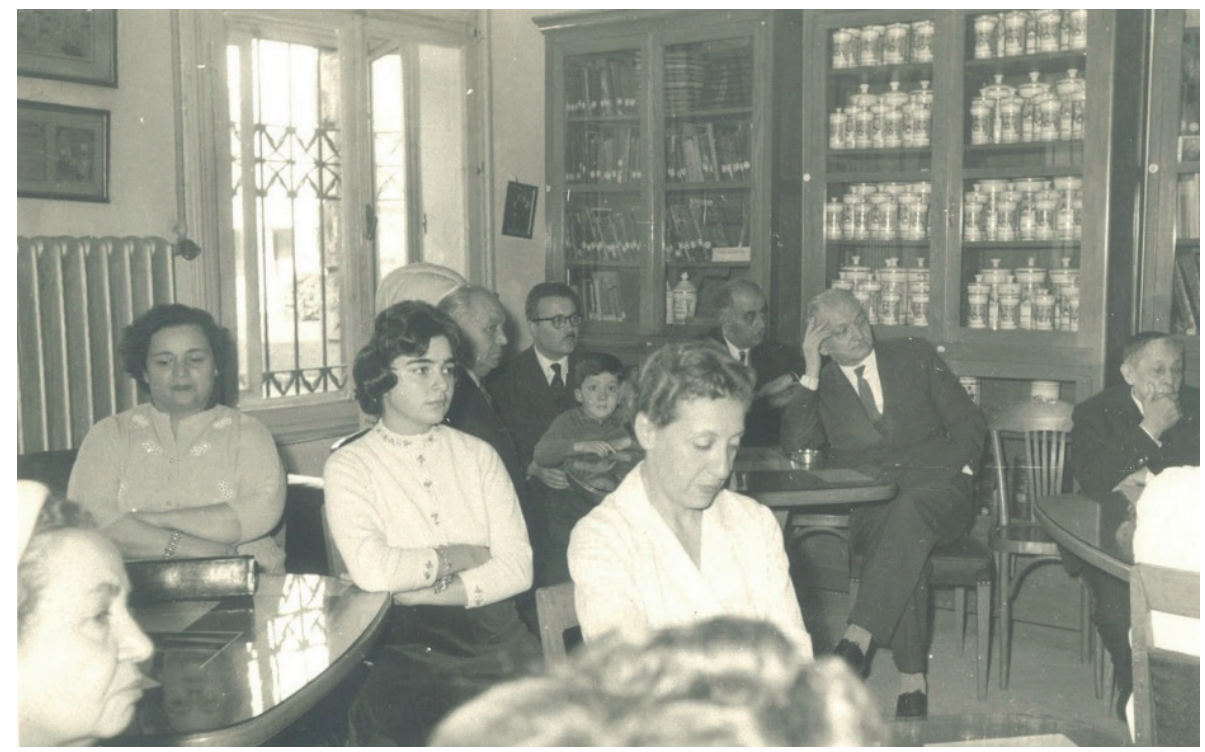

Bedi N. Şehsuvaroğlu'nun düzenlediği Perşembe Toplantıları'ndan biri (1963). Önde soldan sağa ikinci Gülbün Ünver Mesara ve Emine Melek Atabek; arkada sağdan sola Ressam Ali Sami Boyar, Em. Gen. Fahri Belen, ?, Bedi N. Şehsuvaroğlu ve Em. Gen. Nazmi Çağan (Nuran Yıldırım Arşivi).

51 Yakın arkadaşı Dr. Kemal Özbay, Türk Asker Hekimliği ve Asker Hastaneleri (İstanbul: İstanbul Matbaası, 1976) kitabını yazarken sık sık kürsüye gelir Bedi Hocayla fikir alışverişinde bulunurdu. 
Şehsuvaroğlu, Türk resim sanatını çağdaş akımlarla tanıştıran Ali Sami Boyar'ın 77. doğum günü nedeniyle, Tıp Tarihi Kürsüsü'nde 33 tablosunu sergilemiş ve hakkında yazılanları yayımlamıştır: Ressam Ali Sami Boyar. A Well known Turkish Painter, der. Bedi N. Şehsuvaroğlu (İstanbul: İsmail Akgün Matbaası, 1959. Türkçe, İngilizce). Sunuş yazısı Bedi Bey'in ufkunun genişliğini yansıtır. Bu kitabın yayınlanmasından son derece mütehassis olan Ali Sami Boyar, Selami A. Şehsuvaroğlu'nda bulunan kitabın iç kapağında duygularını şöyle dile getirmişti:

Güzel sanat garpta bir meslek memleketimizde ise tedavisi güç bir illettir. Müntesipleri de benim gibi malûllerdir. Yani, gururun, ihmalin ve cehaletin tekmesiyle yaralanmış ve sakatlanmış bir alay sanat savaşı malûlleri. Kitabınız korkak ve cesareti kırılmış mütevazi bir sanatkârın yaralı ruhuna sunulmuş hâzık bir doktor reçetesidir. Bu değerli reçete Tıp Tarihi Enstitüsü'nde yazıldı. Zarfın mazrufa verdiği şerefle ne kadar övünsem yeridir. Ali Sami Boyar, 3 Ocak 1959.

“Ressam Murteza Elker” [(Üsküdar Gençlik Sesi 3, 4 (1966)], “Avni Lifij’in Resim Sergisi” (Tercüman, 8 Temmuz 1968) makaleleri de resme ilgisinin nişaneleri arasındadır.

Ressam Feyhaman Duran'ın (1886-1970) eşi Güzin Duran, Şehsuvaroğlu'nun yönlendirmesiyle, atölye olarak da kullandıkları Beyazıt'taki evlerini İstanbul Üniversitesi'ne bağışlamıştır. Bu evin içindeki sanat eserlerinin ilk tespiti 1970'lerin başında Tıp Tarihi Kürsüsü mensupları tarafından yapılmış, uzun süre kapalı duran ev sonraları İstanbul Üniversitesi tarafından restore ettirilip, "Feyhaman Duran Kültür ve Sanat Evi” adıyla ziyarete açılmıştır (2001). ${ }^{52}$

Şehsuvaroğlu, sanat tarihçisi ve ressam arkadaşı Celal Esat Arseven'in (1876-1971) resimlerini, vefatından bir yıl önce, Galatasaray'daki Yapı Kredi Bankası salonunda sergilemişti.

Yakın çevresinde bulunduğu, Türk Edebiyatı Tarihçisi Sadettin Nüzhet Ergun hakkında bir makale ["Sadettin Nüzhet Ergun," Bilgi Mecmuası 12, 145 (1959):12-13, 17] ve Muzaffer Gökmen ile bir de kitapçık yazmıştır: Sadettin Nüzhet Ergun (1901-1946): Öğretmen, Edebiyat Tarihçisi, Yazar ve Kütüphaneci (İstanbul: İstanbul Şehir Kütüphanesi Kurma ve Yaşatma Derneği, 1976).

52 Feyhaman Duran'ın eserleri 12 Ocak-21 Temmuz 2017 tarihlerinde, "Feyhaman Duran İki Dünya Arasında" adıyla Sakıp Sabancı Müzesi’nde sergilenmiştir. 


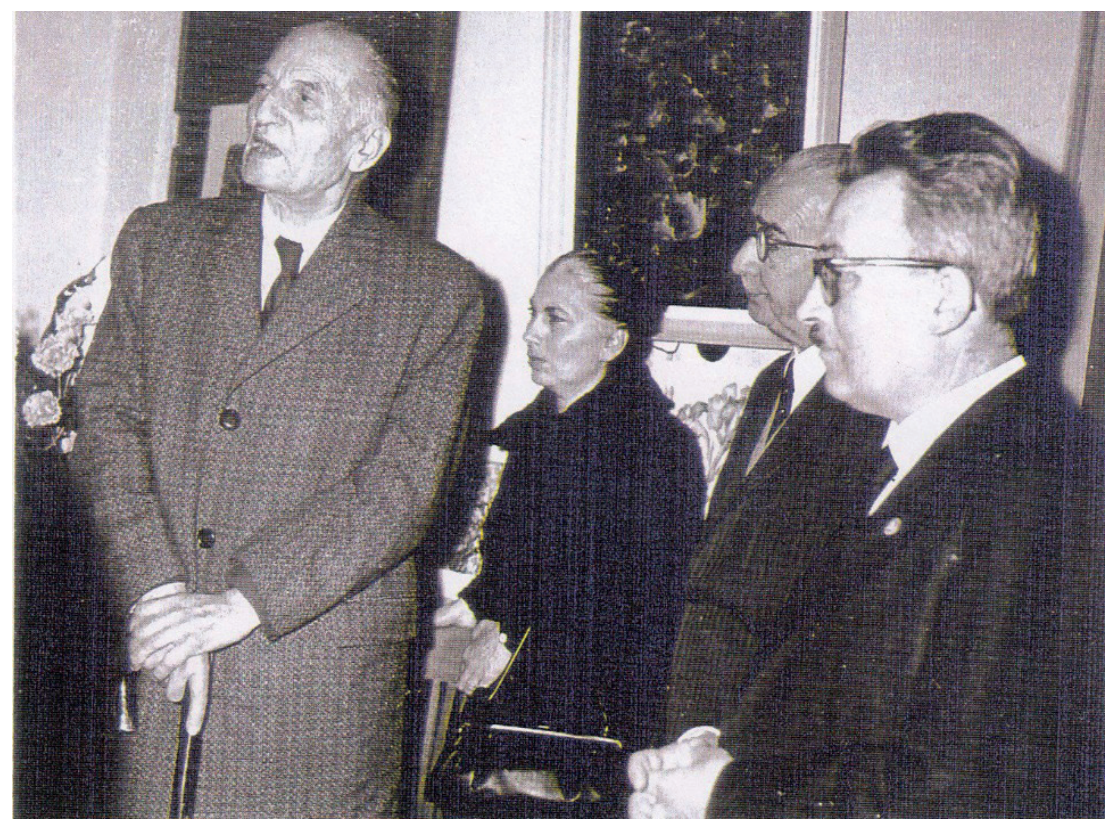

İstanbul Darülfünunu'nun 1925 yılında Beyazıt'a taşınmasının 40. yılı münasebetiyle Fadime Baltacıoğlu'nun açtığı resim sergisinde (1965). Soldan sağa, taşınma sırasında Darülfünun emini / rektörü (1924-1927) olan Ismayıl Hakk1 Baltacığlu (1886-1978), Samime Baltacıŏlu (1914-1975),

Süheyl Ünver (1898-1986), ve Bedi N. Şehsuvaroğlu (1914-1977) (Ali Baltacıŏlu Arşivi).

Son İstanbul Efendilerinden biri olan Şehsuvaroğlu, 1933’te Vakit gazetesinde, "Bedi Nuri” imzasıyla yayınlanan ilk makalesiyle başladığı köşe yazılarını; Vatan, Yeni İstanbul, Yeni Gazete, Akşam, Milliyet, Son Posta, Dünya, Tercüman ve Cumhuriyet gazetelerinde sürdürmüştür. Gazete yazılarında; gündemdeki olayların tarihlerine değinir, şiddetli bir kış yaşanıyorsa, İstanbul'un eski kışlarını anlatırdı. Doğup büyüdüğü İstanbul'u köprüleri, anıtları, kapalı çarşısı, çeşmeleri, sebilleri, dikilitaşları, müzeleri, sarayları, surları, yangınlarıyla anlatır özellikle İstanbulluları yaşadıkları şehrin tarihi konusunda aydınlatmaya çalışırdı. Gazete makalelerinde tarihi konulara da değinirdi. “Asırlar Boyunca Kıbrıs” başlıklı yazısı Yeni Gazete'de 45 gün tefrika edilmişti (1958). II. Abdülhamit'in hayatını ve saltanat yıllarını ayrıntılı olarak anlattığı "Sultan Abdülhamit" başlıklı yazısı da 10 Ocak - 7 Nisan 1968 tarihleri arasında 86 gün Tercüman'da tefrika edilmiştir. Gazete yazılarıyla ayrıca başta salgın ve bulaşıcı hastalıklar olmak üzere çeşitli sağlık konularında halkı bilinçlendirmeye de özen gösterirdi. 1947-55 yılları arasında gazetelerde 250 yazısı yayınlanmış, ayrıca 20 radyo konuşması yapmıştır.

Şehirdeki harap olmuş tarihi eserlere sahip çıkar ve ihya edilmeleri için uğraşırdı. Yoğun çabalarıyla yeniden yapılan Simkeşhâne (ilk darphane binası) günümüzde kütüphane olarak 
kullanılmaktadır. İstanbul-Laleli'deki Tauris Forumu'nun bulunduğu alana, 1463 'te yapılan Simkeşhâne, depremler ve yangınlardan zarar görmüş ve 18. yüzyılın ilk yıllarında üst yapısı değiştirilmişti. Zamanla harap olan binanın ön cephesi, Divanyolu genişletilirken yıkılmıştı (1957-58). Şehsuvaroğlu, İstanbul Üniversitesi yakınındaki bu binayı ayağa kaldırıp bir kültür sitesi yapmak istiyordu. Bu düşüncesini gerçekleştirmek üzere, İstanbul Şehir Kütüphanesi Kurma ve Yaşatma Derneği'ni kurdu ve başkanlığını üstlendi (1963). Kurucu üyeleri özenle seçmiş; vali, belediye başkanı İstanbul Üniversitesi Rektörü, Milli Eğitim Bakanlığı Kütüphaneler Umum Müdürü ayrıca İstanbul'daki bütün önemli kütüphanelerinin müdürlerini, şehir kütüphanesi kurma ülküsüyle bir araya getirmişti. Dernek, Simkeşhâne binasını 49 yıllığına kiralayarak onarım çalışmalarına başladı. Mimar İlban Öz’ün yürüttüğü çalışmalar sırasında kazılardan çıkan Tauris Forumu'na ait parçalar bir açık hava müzesi şeklinde yolun kenarına yerleştirildi. "Bayezid Meydanı ve Tarihî Simkeşhane" (Tercüman, 26 Şubat 1968), "Fatih Devri Yadigârı Bir Anıt: Simkeşhane” (Yeni Asya, 24 Ağustos 1970) yazılarıyla bu tarihi yapıya ilgi çekmek isteyen Şehsuvaroğlu, Simkeşhâne'de geceleri de hizmet verecek bir kütüphane kurmak, çevrede yoğun olarak çalışan genç çırakları iş bitiminden sonra, çeşitli kültür faaliyetleriyle buraya çekmek ve akşamları onları çeşitli kurslarla eğitmek niyetindeydi. Şehir Kütüphanesi Kurma ve Yaşatma Derneği'ni bu amaçla kurmuştu. ${ }^{53}$ Bir yandan onarım çalışmalarına başlamak için resmi makamlarla görüşmeler yapıyor, bir yandan da bağış yoluyla kitap biriktiriyordu. Zengin kitaplığını Şehir Kütüphanesi Kurma ve Yaşatma Derneği'ne bağışlayan dostu Büyükelçi Dr. Hulusi Fuat Tugay’a, bir kitapla teşekkür etmişti: Hekim Bir Siyasimizin Portresi, Büyükelçi Doktor A. Hulusi Fuad Tugay (İstanbul: 1972).

Kültür Bakanlığı'ndan sağladığı destekle onarım çalışmaları 1976 yılında tamamlandı. Fakat ne yazık ki Şehsuvaroğlu kısa bir süre sonra hayata veda etti ve yoğun emeklerle yoktan var ettiği Simkeşhâne'nin kütüphane olarak faaliyete geçtiğini göremedi. Kültür Bakanlığı, 16 Kasım 1981'de İstanbul İl Halk Kütüphanesi'ni Simkeşhâne’ye yerleştirdi. Daha sonra İstanbul Orhan Kemal İl Halk Kütüphanesi adı verilen (2001) kütüphane günümüzde de faaliyetini sürdürmektedir. ${ }^{54}$ Şehsuvaroğlu, öldükten sonra da olsa İstanbul'a bir kütüphane kazandırmayı başarmıştı. Doğumunun 90. yılında, 8 Nisan 2005'te bu kütüphanede düzenlenen "Prof. Dr. Bedii N. Şehsuvaroğlu 90 Yaşında" başlıklı bir etkinlikle hizmetleri anıldı. Bu anma töreni, T. C. Kültür ve Turizm Bakanlığı İstanbul Orhan Kemal İl Halk Kütüphanesi Kültür Etkinlikleri çerçevesinde düzenlendi.

53 İstanbul Şehir Kütüphanesi Kurma ve Yaşatma Tüzüğü (İstanbul: [yayl. y.], 1975).

54 Gönül Cantay, "Simkeşhane,” Dünden Bugüne İstanbul Ansiklopedisi, c.6 (İstanbul: Kültür Bakanlığ ve Tariih Vakfi, 1994), 561. 


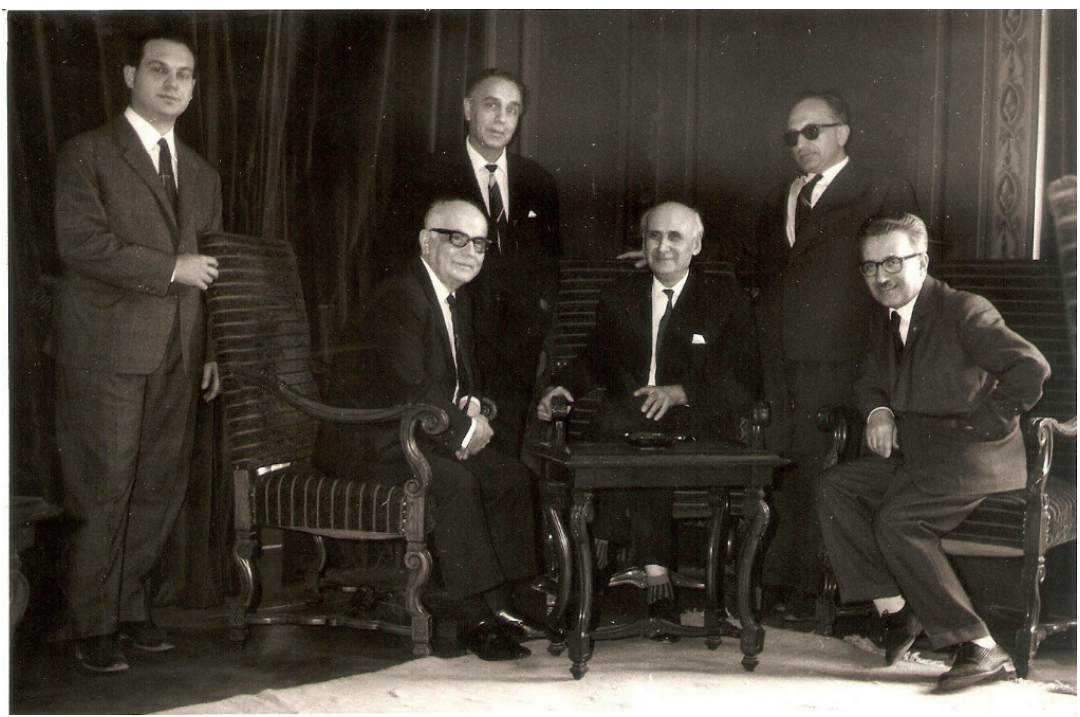

Soldan sağa oturanlar: İstanbul Üniversitesi Rektörü Prof. Dr. Ekrem Şerif Egeli (1901-1980); Union médicale balkanique'in Genel Sekreteri Prof. Dr. Mitica Popescu-Buzeu (1901-1999) ve Prof. Dr. Bedi N. Şehsuvaroğlu (Selami Ahmet Şehsuvaroğlu Arşivi).

İstanbul Üniversitesi Edebiyat Fakültesi yanındaki tarihi II. Bayezit Hamamı'nda bir planetaryum kurulmasını önererek bu yapıya bilimsel bir fonksiyon verilmesi yolunda epey uğraşan Şehsuvaroğlu'nun bu çabaları sonuçsuz kalmıştır. Bu hamam uzun yıllar sonra, İstanbul Üniversitesi tarafından restore ettirilip, "II. Bayezid Türk Hamam Kültürü Müzesi” adıyla ziyarete açılmıştır (2015).

Göztepe'de oturan Şehsuvaroğlu, çocuklarına yaşadıkları semti anlatan birer defter bırakmak isteğiyle araştırmaya başlamış önce, “Göztepe'nin Tarihçesi” (Tarih Konuşuyor Dergisi, 5, 28 1966), “Göztepe Monografisi” (Tercüman, 6 Şubat 1967) makalelerini yazmış, daha sonra geliştirip kitap olarak yayımlamıştı. Göztepe adıyla (İstanbul: Türkiye Turing ve Otomobil Kurumu, 1969) yayınlanan bu kitapta semtin tarihi, tarihi mekânları, mektepleri, mesireleri, ünlüleri, günümüzde bahçelerine yapılan apartmanlar arasına sıkışmış köşk ve yalıları resimleriyle tanıtır. Bu kitabı ve "Kalamış Semti ve Fuad Paşa" (Tercüman, 19 Aralık 1966), “Çocukluğumun İstanbul'u” (Tercüman, 26 Aralık 1966) gibi yazılarıyla semt tarihi yazımının öncülüğünü yapmıştır. Semt tarihçiliği yakın zamanlarda önem kazanmış ve İstanbul semtlerinin tarihi peş peşe yazılıp yayınlanmaya başlamıştır.

Göztepe için bugüne kadar hiçbir şey yazılmamış. Fakat araştırdıkça ele o kadar çok bilgi ve çeşitli hatıralar geçti ki!.. İşte bu küçük eser o gayretlerin meyvalarıdır. Çocuklarıma ve onlardan farksız bildiğim her Türk çocuğuna armağan olsun, onlar da bu gibi çalışmalardan örnek alarak Türk kültürünün bir dalına sahip olmayı öğrensinler... (Önsöz'den) 
Mezarlıkların dini olduğu kadar, kültürel önemleri olduğuna da inanır ve onları doğal tapular olarak nitelendirirdi. Mezar taşlarının ise tarih ve güzel sanatlar bakımından anıtsal eserler olduklarını dile getirirdi. Bu nedenle, Behçetî İsmail Hakkı el-Üsküdarî’nin Karacaahmet mezarlığında 30 yıl inceleme yaparak hazırlamış olduğu eserini Latin harflerine çevirip yayınlamıştı: Merakid-i Mu’tebere-i Üsküdar. Ünlülerin Mezarları, haz., Bedi N. Şehsuvaroğlu (İstanbul: Türkiye Turing ve Otomobil Kurumu, 1976).

Klasik Türk müziğini çok severdi. Bu konuda makaleler yayınlamış ve yakın dostu, Türk dinî mûsikisinin son temsilcilerinden Halil Can'ın yaşamını anlatan bir kitap yayınlamıştı: Eczacı Yarbay Nâyzen Halil Can (1905-1973) (İstanbul: Hüsnütabiat Matbaas1, 1974). Bir Perşembe toplantısında, sevgili arkadaşı Mevlevi dostu Rebabzen Sabahattin Volkan, beraberinde getirdiği rebab ile katılanlara müzik ziyafeti sunmuştu.

Dr. A. Adnan Adıvar ve Halide Edip Adıvar ile yakın dostluğu vardı. Sık sık Laleli' deki evlerine giderdi. Bu dostluk neticesinde, biri bilim tarihinde öne çıkmış diğeri edebiyat alanında romanlarıyla ün kazanmış bu iki müstesna insanın bütün evrakını Tıp Tarihi Kürsüsü'ne bağışlamalarını sağlamıştı.

Şehsuvaroğlu, 1970'li yılların ortalarında bir gün kitap dolu birkaç çuvalla geldi kürsüye. "Şair Celâl Sılay’ın kitapları" dedi. Yersizlik nedeniyle çuvallar depoya kondu. Seneler sonra bir gün Doğan Hızlan nereden duymuşsa, Celâl Sılay’ın kitaplarından birer adet istedi. Piyasada bulunmuyormuş. Nasıl bulunsun, çoğu satılamadan elde kalmış olmalı. Depoya girip çuvallardan bir takım seçtim, birini gönderip aldırdı. Doğan Hızlan'ın, Celâl Sılay’ın toplu şiirlerini, Hüsran Filizleri (İstanbul: Yapı Kredi Yayınları, 2000) adıyla yayınladığını çok sonra öğrenecektim. Celal Sılay’ın kitapları Şehsuvaroğlu tarafından Tıp Tarihi ve Deontoloji Kürsüsü'ne mâl edilmemiş olsaydı ya yok olup gidecek ya da sahaflara düşüp dağılacaktı.

Şehsuvaroğlu, kültür hizmetlerinin bir bakanlık tarafından yürütülmesi gerektiğini düşünmüş ve Yeni Gazete'de 9 Şubat 1966 günü yazdığı, "Kültür Bakanlığı Kurulmalıdır” başlıklı yazısında bakanlığın yararlarını dile getirmişti. Bilindiği gibi Kültür Bakanlığı birkaç sene sonra kurulmuş ve Talât Sait Halman, ilk kültür bakanı olarak göreve başlamıştı (13 Temmuz 1971).

\section{Vefatı}

Özlük dosyasındaki sağlık raporlarına göre, 7 Ocak 1954'te, arka cidar miyokard enfarktüsü tanısıyla bir süre hastanede yatmış ve evinde dinlenmişti. On sene sonra 22 Ekim 1966 günü üniversiteye gelirken yolda başlayan şiddetli göğüs sancısı nedeniyle âcilen Haydarpaşa Numune Hastanesi'ne kaldırılmış ve ilk hastalığında olduğu gibi arkadaşı Dr. Müfit Ekdal tarafindan tedavi edilmişti. 
Sağlığına dikkat eder, öğlenleri eşi Leyla Hanım'ın hazırladığg bir sandviç ile bir meyveden başka bir şey yemezdi. 1977 başlarında annesi hastaydı. Ona bakmak üzere bir hemşire tutmuştu. Annesini ziyaretten geldiği bir gün, "kötüye gidiyor" demiş ve annesinin ölüm ilânını hazırlayıp çalışma masamın camı altına koydurmuş; "İstanbul dışındayken anneme emr-i Hakk vâki olursa bizimkilere verirsin" demişti.

1977 ilkbaharında Simkeşhane binasının restorasyonu bitmişti. Belediye İmar Müdürlüğü, burada açılması düşünülen kütüphaneye gelir sağlamak amacıyla giriş katında dükkân olarak kullanılması planlanan mekânlar için, oldukça geniş bir otopark alanını şart koşuyor ve iskân izni vermiyordu. Beyazıt gibi şehrin merkezindeki bir iş merkezinde, istenilen büyüklükte otopark alanı bulmak mümkün değildi. Şehsuvaroğlu, Mayıs 1977 başlarında bu soruna bir çözüm bulmak için vilayet ile belediye arasında âdeta mekik dokuyordu, çok üzgündü.

13 Mayıs 1977 Cuma günü, üniversiteye gelmek üzere evden çıktıktan sonra, on sene önce olduğu gibi, kalp krizi nedeniyle fenalaşmış, yoldan geçenler tarafından yine Haydarpaşa Numune Hastanesi'ne götürülürken vefat etmişti. Hayata veda ettiği haberi geldikten sonra, ölüm ilânını çıkarıp aileye teslim ettim. Annesi için hazırladığı ölüm ilânı, isimlerin yeri değiştirilerek gazetelerde yayınlandı. Oğlu Selami Ahmet, Amerika'dan gelince, İstanbul Üniversitesi'nin merkez binasında yapılan tören ve Beyazıt Camii’nde kılınan öğle namazından sonra Karacaahmet Mezarlığı'ndaki aile kabristanına defnedildi (17 Mayıs 1977 Salı). Annesi Şefika Nûrünnisa Hanım yaşıyordu.

Vefatının ardından hocamdan öğrendiğim gibi bir defter alarak cenazesine katılan kimi arkadaşlarından duygularını yazmalarını rica ettim. Basında çıkan vefat haberlerini ve ilanları kesip toparladım. İstanbul Üniversitesi’nden Karacaahmet Mezarlığı'na kadar çekilen fotoğrafları zarfladım. Vefatının 1., 2. ve 5. yıllarında yapılan anma toplantılarının davetiyelerini saklayıp katılanların imzalarını aldım. Defnedildiği gün Dr. Müfid Ekdal bu hüzün defterine şunları yazmıştı:

Dost, arkadaş, herkesin derdine koşan candan Bedi, ölümle karşılaştığın iki kez, geçirdiğin iki infarktüste de ben başındaydım. Elimden geleni yaptım. Fakat son defa hiçbir şey yapmaya imkân olmayacak şekilde ve her şeyin bittiği bir anda yine beraber olduk. Acım, ıztırabım çok büyük. Seni kaybettim. Sevgili dostum. 17 Mayıs 1977.

Beklenmedik bir zamanda, henüz emekli bile olmadan 62 yaşında bu dünyadan ayrılmasıyla, Tıp Tarihi ve Deontoloji Kürsüsü’nün de kaderi değişmiştir. Yorgun kalbi üçüncü kalp krizine yenik düşmeseydi Türk Tıp Tarihi bugün daha farklı bir yerde olabilirdi. Ruhu şâd olsun. 


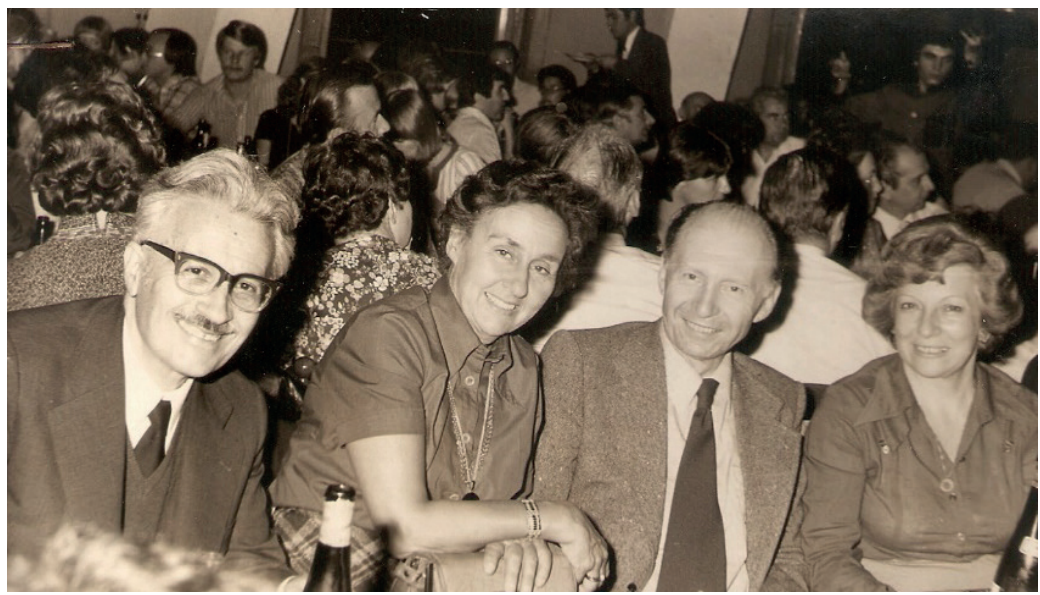

Bedi N. Şehsuvaroğlu (solda), Münih Tıp Tarihi Kurumu ile İstanbul'da ortaklaşa düzenlemiş olduğu

Tarihte Türk-Alman Tibbi Illişkileri Sempozyumu'nda. Sağdan sola: Leyla Şehsuvaroğlu, Heinz Goerke (1917-2014) ve eşi,

17 Ekim 1976 (Selami Ahmet Şehsuvaroğlu Arşivi).

Teşekkür / Acknowledgements: Verdiği bilgiler ile göndermiş olduğu belgeler ve fotoğraflar için Selami Ahmet Şehsuvaroğlu'na, Prof. Dr. Bedi N. Şehsuvaroğlu'nun öğrenci ve personel arşivindeki dosyalarını incelememe izin veren İ.Ü. İstanbul Tıp Fakültesi Dekanlığı'na teşekkür ederim.

\section{KAYNAKÇA / BIBLIOGRAPHY}

\section{Arşiv Kaynakları / Archival Sources}

Ali Baltacığlu Arşivi (Ankara)

İstanbul Üniversitesi İstanbul Tıp Fakültesi'ndeki Bedi N. Şehsuvaroğlu arşivi (İstanbul). İstanbul Üniversitesi İstanbul Tıp Fakültesi Dekanlığı öğrenci ve personel arşivi (İstanbul) İstanbul Üniversitesi-Cerrahpaşa, Cerrahpaşa Tıp Fakültesi Tıp Tarihi ve Etik Anabilim Dalı Arşivi (İstanbul) Nuran Yıldırım Arşivi (İstanbul).

Selami Ahmet Şehsuvaroğlu Arşivi (Nice).

\section{Basılı Kaynaklar / Printed Sources}

Arabacıoğlu, Celal. Tip Fakültelerimizde Tip Tarihi ve Deontoloji Anabilim Dallarl (1991 yll itibariyle). Adana: Çukurova Üniversitesi Tıp Fakültesi Tıp Tarihi ve Deontoloji Anabilim Dalı Yayın No.3, 1992. Baylav, Naşid. Eczacılık Tarihi, İstanbul: Yörük Matbaası, 1968.

Baytop, Turhan. Türk Eczacıllk Tarihi. İstanbul: İstanbul Üniversitesi Eczacıllk Fakültesi, 1985, 
I. Milletlerarası Türkoloji Kongresi (First International Congress of Turcology) 15-20 / X / 1973 Istanbul. Gündem (Programme). İstanbul: İstanbul Üniversitesi Edebiyat Fakültesi, 1973.

Cantay, Gönül. “Simkeşhane.” Dünden Bugüne İstanbul Ansiklopedisi. 6: 561. İstanbul: Kültür Bakanlığı ve Tarih Vakfi, 1994.

Cantay, Gönül. "Prof. Dr. Bedii Nuri Şehsuvaroğlu'nun Türk Tıp Tarihi ve Deontoloji Bilimine Katkıları," III. Türk Tlp Tarihi Kongresi: İstanbul 20-23 Eylül 1993: Kongreye Sunulan Bildiriler içinde 159-165. Ankara: Türk Tarih Kurumu, 1999.

Cantay, Gönül Güreşsever. “Anadolu Türk Mimarisinde Darüşşifalar (Hastahaneler)'1n Gelişmesi.” Doçentlik Tezi, İstanbul Üniversitesi, 1982.

Cantay, Gönül Güreşsever. Osmanlı Menzil Kervansarayları. İstanbul: Fatih Sultan Mehmed Üniversitesi Yayınları, 2016.

Cantay, Gönül Güreşsever. “İstanbul Tıp Fakültesi Tıp Tarihi Müzesi Anılarım.” Sağlık Tarihi ve Müzeciliği Sempozyumu 3, 19-21 Mayıs 2017, editörler Semih Atış ve Murat D. Çekin içinde, 163-170. İstanbul: Zeytinburnu Belediyesi Kültür Yayınları, 2018.

“Ceramikcenter On’lar Gurubu Resim ve Heykel Sergisi (5-10 Mayıs 1990).” Milliyet, 6 Mayıs 1990.

Çağan, Nazmi. Dr. Bedii N Şehsuvaroğlu Biyografi ve Bibliyografyası (1948-1960). İstanbul: İstanbul Üniversitesi Tıp Tarihi Enstitüsü Yayın No. 59, 1963.

Çağan, Nazmi. Bedi N. Şehsuvaroğlu Biyografi ve Bibliyografyası II (1947-1970). İstanbul: İstanbul Şehir Kütüphanesi Kurma ve Yaşatma Derneği, 1973.

Demirsoy, Nilüfer, ve Ömür Şaylıgil. "Hazâ'inü's-Sa’âdât'ta Yenidoğan Bakımı Hakkında Bilgiler: XIV-XV. Yüzyıldan Bir Yazma Eser.” Lokman Hekim Dergisi 8, 3 (2018): 240-246.

Efeoğlu, Ahmet. Dişhekimliği Tarihi. İstanbul: İstanbul Üniversitesi, 1992.

Ertin, Hakan, ve Ceren İlikan Rasimoğlu. "Nuran Yıldırım ile Tıp Tarihi Kariyeri Üzerine." Nuran Yıldırım Armağan Kitabı Tıp Tarihinin Peşinde Bir Ömür, editörler Hakan Ertin ve M. İnanç Özekmekçi içinde 11-45. İstanbul: BETIM, 2016.

Etker, Şeref, Feza Günergun, ve Abdullah Köşe. "Zeynep-Kamil Hastanesi’nin Kuruluşu ve Vakfiyesi.” Osmanlı Bilimi Araştırmaları 5, 2 (2004): 1-37.

Etker, Şeref, ve Feza Günergun. "Zeynep Kâmil Hastanesi (1875): Romantik Tarihçiliğin Gölgesinden Bir Çıkış Denemesi." Prof. Dr. Ali Haydar Bayat Anısına Düzenlenen Osmanlı Sağllk Kurumları Sempozyuтu - 2 Haziran 2007, editörler Bülent Özatalay, Nuran Yıldırım, Murat Çekin içinde 147-170. İstanbul: Zeytinburnu Belediyesi, 2008.

Gümüşel, Günseli. "Erkekler İçin Askerliğe Hazırlık Dersleri.” Çanakkale Araştırmaları Türk Yıllığı 15, 22 (Bahar 2017): 1-40.

İlhan, Nadir. "Eşref bin Muhammed Haza'inu's-Sa'adat (İnceleme-Metin-Dizin)." Doktora tezi, Fırat Üniversitesi, 1998.

İlhan, Nadir. Eşref b. Muhammed, Haza 'inu 's-Sa'adat: İnceleme, Metin, Sözlük. Malatya: Serhat Yayınları, 2009. İstanbul Şehir Kütüphanesi Kurma ve Yaşatma Tüzügü̈. İstanbul: [yayl. y.], 1975.

İstanbul Tip Kurultayl 25-30 Eylül 1977. I. Türk Tıbbi Deontoloji Kongresi Bildiri Özetleri. Istanbul Medical Convention 25-30 September 1977. 1st Congress On Medical Deontology Abstracts of Communications. İstanbul: Sermet Matbaası, 1977. 
“İstanbul Üniversitesi Tıp Tarihi Enstitüsünden.” Cumhuriyet, 28 Kasım 1935.

İstanbul Üniversitesi Eczacllı Fakültesi 1962-2002. Hazırlayanlar Turhan Baytop, Afife Mat, Nuriye Akev, Eser İlhan, Yıldız Özsoy Erginer. İstanbul: [yayl. y.], 2002.

Karaata, Ceylan Akgün. "Ord. Prof. Dr. Ahmet Süheyl Ünver'in Türk Süsleme Sanatı Eğitimine Katkıları.” Yüksek Lisans tezi, Gazi Üniversitesi, 2006.

Kazancigil, Aykut, ve Vural Solok. Türk Bilim Tarihi Bibliyografyası (1850-1981). İstanbul: İstanbul Üniversitesi Cerrahpaşa Tıp Fakültesi, 1981.

Kirmizialtin, Suphan. Gender, Education, Modernization: Women School Teachers in the Late Ottoman Empire. Doctoral dissertation, University of Texas, 2012.

Marmara Üniversitesi Eczacllık Fakültesi'nin 50. Ylll. Hazırlayanlar Gülten Z. Omurtag, Emre Dölen, Mesut Sancar, Kübra Elçioğlu, Gülbin Erdoğan, ve Eyüp Talha Kocacık. İstanbul: Marmara Üniversitesi, 2013.

Nouridjan, Joseph. Précis de Déontologie médicale. Cours élémantaire professé à l'Ecole impériale de Médecine de Constantinople. Constantinople: [yayl. y.], 1877.

Özbay, Kemal. Türk Asker Hekimliği ve Asker Hastaneleri. İstanbul: İstanbul Matbaası, 1976.

Riza Tahsin. Mir'ât-ı Mekteb-i Tibbiye. İkinci Kitap. [Dersaadet]: [Kader Matbaas1], 1328 [1912].

Sayar, Ahmet Güner. A. Süheyl Ünver: Hayatı, Şahsiyeti ve Eserleri (1898-1986), 4. bs. İstanbul: Ötüken Neşriyat, 2016.

Şehsuvaroğlu, Bedi N. "Memleketimizde Tip Tarihi ve Deontoloji Öğretimi ve İstanbul Tip Fakültesi Tıp Tarihi Enstitüsü." İstanbul Üniversitesi Tıp Fakültesi Mecmuası 32 (1970): 368-375.

Şehsuvaroğlu, Bedi N. Eczacllık Tarihi Dersleri. İstanbul: İstanbul Üniversitesi Eczacılık Fakültesi, 1970.

Şehsuvaroğlu, Bedi N. "Türkiye'de Sağlıkla İlgili Olarak Yayınlanan Periyodikler.” İstanbul Tıp Fakültesi Mecmuası 36, 1 (1973):169-198.

Şehsuvaroğlu, Bedi N. Tıbbi Deontoloji Dersleri. İstanbul: Hüsnütabiat Matbaası, 1975.

Şehsuvaroğlu, Bedi N. Tıbbi Deontoloji. Yayına hazırlayan Arslan Terzioğlu. İstanbul: İstanbul Tıp Fakültesi Vakfi, 1983.

Şehsuvaroğlu, Bedi N. "Anadolu Türk Tıbbının Batılılaşmasında Alman Hekimlerin XIX. Yüzyıl Başlarından Beri Süregelen Etkileri.” Türk-Alman Tıbbî Illişkileri. Simpozyum Bildirileri 18-19 Ekim 1976, İstanbul, yayına hazırlayan Arslan Terzioğlu içinde 17-21. İstanbul: İstanbul Üniversitesi İstanbul Tıp Fakültesi, 1981.

Şehsuvaroğlu, Bedi N. “Tarihte Türk-Alman Tibbi İlişkileri.” İstanbul Tip Fakültesi Mecmuası 40, 3 (1977): 720-737.

Şemseddin Sami. Kamus-ı Türkî. Dersaadet: İkdam Matbaası, 1317.

T.C. Sıhhat ve İçtimai Muavenet Vekâleti Tip Talebe Yurdu Müdürlüğü, Tip Talebe Yurdu Dahili Talimatnamesinden Talebeyi Alâkalandıran Bazı Maddeler. İstanbul: Matbaa-yı Ebüzziya, 1933.

Terzioğlu, Arslan. “Atatürk’ün Son Hastalığı ve Tedavisinde Kullanılan Tıbbî Aletler.” Bifaskop 4, 2 (Nisan 1981): 2-8.

Terzioğlu, Arslan. "Türkiye'de Görev Yapmış Olan Alman Asıllı Tıp ve Deneysel Bilim Dallarındaki Profesörlerin Biyografileri (Alfabetik).” Türk-Alman Tıbbî Illişkileri. Simpozyum Bildirileri 18-19 Ekim 1976, İstanbul, yayına hazırlayan Arslan Terzioğlu içinde 131-216. İstanbul: İstanbul Üniversitesi İstanbul Tip Fakültesi, 1981. 
Toprak, Zafer. Türkiye’de Kadın Özgürlüğ̈̈ ve Feminizm (1908-1935). İstanbul: Tarih Vakfi Yurt Yayınları, 2014. Türk Kadın Birliği Kadın Sesi Cumhuriyetin 10uncu Yıldönümünü Kutlular, 1923 - 1933. İstanbul: Ahmet İhsan Matbaası, 1933.

Ünver, A. Süheyl, Bedi N. Şehsuvaroğlu, ve Emine M. Atabek. Zeyneb-Kâmil Hastahanesi, 1860-1960. Yayına hazırlayan Bedi N. Şehsuvaroğlu. [İstanbul]: Kaptanoğlu Matbaası, 1960.

Üstün, Çağatay. "Ege Üniversitesi Tıp Fakültesi’nin Eğitim ve Öğretime Başladığı 9 Mart 1956 Günü Yapılan Konuşmalar ve Aç1lış Dersi Üzerine Bir Değerlendirme." İzmir'in Sağllk Tarihi Kongresi, 1-3 Aralık 2005, Bildiriler, editörler Eren Akçiçek ve Onur Kınlı içinde 347-359. İzmir: 2009.

Yıldırım, Nuran. "XV. Yüzyıla Ait Türkçe Bir Cerrahnâme (Doktora Tezi Özeti).” Doktora Tezleri. İstanbul Tip Fakültesi Mecmuası 46, Supplementum 90 içinde 227-246. İstanbul: İstanbul Tıp Fakültesi, 1983.

Yıldırım, Nuran, ve Yeşim Işı1 Ülman. "Başlangıcından Günümüze İstanbul Üniversitesi'nde Tıp Tarihi ve Deontoloji Eğitimi Tarihine Bir Bakış." Uluslararası Katılımlı 3. Ulusal Tıp Etiği Kongresi Kongre Kitabl, c. 2, editörler Ayşegül Demirhan Erdemir, İlter Uzel, Öztan Öncel, Oğuz Y. Aksoy ve diğerleri içinde 1109-1116. Bursa: F. Özhan Matbaacılık San. Ltd. Şti., 2003.

Yıldırım, Nuran. "XV. Yüzyıla Ait Anonim Bir Cerrahnâme Cerrahi Yöntemlerin Kullanıldığı Fasıllar Tıbbi Terminoloji ile Bitki, Drog ve Madde İsimleri.” Yeni Tıp Tarihi Araştırmaları sayı 10-11 (2004/2005): 325-433.

Yıldırım, Nuran, ve Hakan Ertin. “İstanbul Tıp Fakültesi Tıp Tarihi Müzesi/Koleksiyonu, 1933-2015.” Sağllk Tarihi Müzeciliği Sempozyumu 1, 24 Mayls 2015, editörler Fatma M. Şen ve Murat D. Çekin içinde 3953. İstanbul: Zeytinburnu Belediyesi Kültür Yayınları, 2016.

Yıldırım, Nuran. "Cerrâhiyye-i İlhâniyye, Şerefeddin Sabuncuoğlu'nun Gözlem ve Deneyimleri, Cerrahi Yöntemler ve Ameliyatlar.” Journal of Turkish Studies/Türklük Bilgisi Araştırmaları 47 (2017), editors Cemal Kafadar and Gönül Alpay Tekin - Festschrift in Honor of the Millet Library's 100th Year and its Founder Alî Emîrî Efendi. Part II, guest editors Günay Kut and Bedri Mermutlu, 297-347. Cambridge, MA: Harvard University, 2017.

Yıldırım, Nuran. "Vefatının 40. Yılında Prof. Dr. Bedi N. Şehsuvaroğlu’nun Türk Tıp Tarihi ve Kültürüne Katkıları.” Sivas Dârüşşifası'nın 800. Yılı Anısına XIII. Türk Tıp Tarihi Kongresi, Sivas, 18-21 Ekim 2017, Program ve Bildiri Özetleri içinde 85. [Sivas: Türk Tip Tarihi Kurumu, 2017], 85.

Yücel, Çağatay. “Dionysos Bayramları ve Şenlikleri.” Sosyal Bilimler Enstitüsü Dergisi 4 (2015): 151-164.

Zihnioğlu, Yaprak: Kadınsız İnkılap, 1. bs. İstanbul: Metis, 2003.

\section{Elektronik Kaynaklar / Electronic Sources}

Baytop, Asuman. "Bir Hastane Hekimi Dr. M. Kâmil Berk (1878-1958), Mesleki Faaliyeti ve Bilimsel Yayınları.” Erişim 16 Haziran 2018. http://www.bilimtarihi.org/pdfs/mehmet_kamil.pdf

"Cowley alumnus now a respected international oil and gas consultant." Erişim 27 Kasım 2018. https://www. cowley.edu/news/releases/2015_16/071216_alumnus_gas_consultant.html 